University of Louisville

ThinkIR: The University of Louisville's Institutional Repository

Electronic Theses and Dissertations

8-2008

\title{
Mutagenic and tumor suppressor functions of DNA polymerase iota in mammalian cells.
}

Lindsey Jay Stallons 1983-

University of Louisville

Follow this and additional works at: https://ir.library.louisville.edu/etd

\section{Recommended Citation}

Stallons, Lindsey Jay 1983-, "Mutagenic and tumor suppressor functions of DNA polymerase iota in mammalian cells." (2008). Electronic Theses and Dissertations. Paper 1370.

https://doi.org/10.18297/etd/1370

This Master's Thesis is brought to you for free and open access by ThinkIR: The University of Louisville's Institutional Repository. It has been accepted for inclusion in Electronic Theses and Dissertations by an authorized administrator of ThinkIR: The University of Louisville's Institutional Repository. This title appears here courtesy of the author, who has retained all other copyrights. For more information, please contact thinkir@louisville.edu. 
By

Lindsey Jay Stallons

B.S., UofL, 2006

\begin{abstract}
A Thesis
Submitted to the Faculty of the Graduate School of the University of Louisville in Partial Fulfillment of the Requirements for the Degree of

Master of Science

Department of Pharmacology and Toxicology

University of Louisville

Louisville, KY
\end{abstract}

August 2008 
Copyright 2008 by Lindsey Jay Stallons

All rights reserved 
MUTAGENIC AND TUMOR SUPPRESSOR FUNCTIONS OF DNA POLYMERASE IOTA IN MAMMALIAN CELLS

By

Lindsey Jay Stallons

B.S., UofL, 2006

A Thesis Approved on

April 28, 2008

By the following Thesis Committee:

Thesis Director 


\section{DEDICATION}

This thesis is dedicated to my wife

Mrs. Stacey Elaine Stallons

who stands by me and supports me while I follow my dreams. 


\section{ACKNOWLEDGMENTS}

I would like to thank my mentor, Dr. W. Glenn McGregor, for his guidance and support. I would also like to thank my other committee members, Drs. Jason Chesney, Ramesh Gupta, Christopher States, Brian Wattenberg, and Wolfgang Zacharias, for their insight into my project. Finally, I would like to thank Tom Burke for passing on his technical knowledge and contributing to the experiments described here. 


\section{ABSTRACT \\ MUTAGENIC AND TUMOR SUPPRESSOR FUNCTIONS OF DNA POLYMERASE IOTA IN MAMMALIAN CELLS \\ Lindsey Jay Stallons}

August 7, 2008

The $\mathrm{Y}$ family of DNA polymerases in higher eukaryotes contains at least four members which are implicated in potentially error-prone replication through unrepaired damage in the genome. These proteins are encoded by the REV1,POLH,POLI, and POLK genes. An inherited deficiency in one of these DNA polymerases (POLn) is the molecular defect in the cancer prone xeroderma pigmentosum (XP) variant syndrome, making POLn the most studied member of this family. However, there exist critical gaps in our knowledge on the function of the other known $Y$ family members (POL I, POL $k$, and REV1). The goal of this proposal is to investigate the in vivo function of DNA POLI, and the hypothesis that DNA polymerase I acts as a mutagenic polymerase in translesion synthesis and as a tumor suppressor through a separate mechanism. To test this hypothesis, the mutagenic effects of chemical carcinogens which form structually different adducts will be examined in cells lacking POLn and/or POLI. To characterize the tumor suppressor function(s) of POLI, cell cycle progression will be monitored after UV in POLı null cells along with global gene expression. Finally, a novel mouse model will be used to determine the effect of poln and/or polı deficiency on UVand chemically-induced skin cancer. 


\section{TABLE OF CONTENTS}

PAGE

DEDICATION

ACKNOWLEDGMENTS

iv

ABSTRACT

v

LIST OF FIGURES

viii

CHAPTER 1: INTRODUCTION

CHAPTER 2: EVALUATE THE MUTAGENIC PROPERTIES OF CHEMICAL CARCINOGENS IN MAMMALIAN FIBROBLASTS DEFICIENT FOR Y-FAMILY POLYMERASES

Introduction

Materials and Methods

Results

Conclusions and Future Directions

CHAPTER 3: INVESTIGATE THE TUMOR SUPPRESSOR ROLE OF MURINE POL IOTA

Introduction

Materials and Methods

Results

Conclusions and Future Directions

CHAPTER 4: CHARACTERIZE THE EFFECT OF POL IOTA DEFICIENCY ON IN VIVO SKIN TUMORIGENESIS USING A NOVEL MOUSE MODEL

Introduction

Materials and Methods 
REFERENCES $40-48$

APPENDIX: List of Abbreviations 


\section{LIST OF FIGURES}

FIGURE

PAGE

1.1 Model for translesion synthesis 5

2.1 Survival of murine fibroblasts after BPDE 21

2.2 Survival after $150 \mathrm{nM}$ BPDE 22

2.3 Mutagenesis after $50 \mathrm{nM}$ BPDE 23

2.4 Cytototoxicity of AAAF in murine fibroblasts 24

3.1 UV-responsive miRNA 32

4.1 Tumor latency of SKH1/hairless $x p a^{-/}$mice 38 


\section{CHAPTER 1}

\section{INTRODUCTION}

The $Y$ family of DNA polymerases in higher eukaryotes contains at least four members that are implicated in potentially error-prone replication through unrepaired damage in the genome. These proteins are encoded by the REV1,POLn, POLI, and POLK genes. An inherited deficiency in one of these DNA polymerases (POL $)$ is the molecular defect in the cancer prone xeroderma pigmentosum (XP) variant syndrome, making POL $\eta$ the most studied member of this family. However, there exist critical gaps in our knowledge on the function of the other known $Y$ family members (POLI, POLK, and REV1). Our goal is to investigate the cellular function of DNA POLI, and we hypothesize that DNA polymerase I acts as a mutagenic polymerase in translesion synthesis and as a tumor suppressor through a separate mechanism. This hypothesis is based on the following observations. First, in vitro studies with purified POLI have characterized its error-prone bypass of damaged DNA templates. Second, our group and others have shown that POLI is active in error-prone bypass of UV damage in vivo.

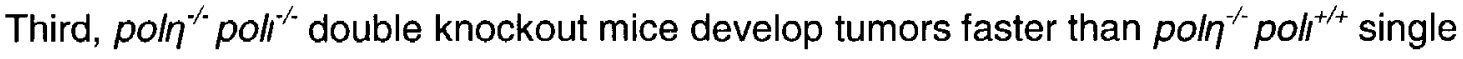
knockouts despite having lower UV-induced mutation frequencies in their fibroblasts. Based on these observations, the focus of this thesis is on the cellular function of DNA POLI.

In Chapter 2, we will evaluate the mutagenic properties of chemical carcinogens in mammalian fibroblasts deficient for Y-family polymerases. We will examine the differential cytotoxic and mutagenic response of human and mouse fibroblasts with 
decreased expression of POLn and/or POLI to benzo[a]pyrene-7,8-diol-9,10-epoxide (BPDE), and N-acetoxy-2-acetylaminofluorene (AAAF). These chemicals form adducts at different positions in the DNA, and this Chapter is proposed to determine the cellular participation of each polymerase in bypassing chemically and structurally different DNA lesions.

Chapter 3 is designed to investigate the tumor suppressor role of murine poll. We propose to test the hypothesis that polı functions as a tumor suppressor in mouse cells. Our group showed that mice that are deficient in both poln and poll have lower UV-induced mutation frequencies, but strikingly develop tumors faster than mice that are deficient in poln alone. This unexpected result is contrary to the somatic mutation hypothesis of cancer and implies that polı has tumor suppressor activity that may be independent of its mutagenic TLS activity. To investigate this, we propose to examine the effect of poll deficiency on miRNA, gene expression, and cell cycle checkpoints induced by UV or genotoxic carcinogens.

Finally, we will characterize the effect of poll deficiency on in vivo skin tumorigenesis using a novel mouse model in Chapter 4. We hypothesize that deficiency in poll alone is sufficient to promote progression of skin cancer caused by UV and benzo[a]pyrene $(\mathrm{B}[\mathrm{a}] \mathrm{P})$. Previous studies using C57BL/6J mice required UV treatment for 20 weeks, after which neither wild type nor polit animals developed tumors. Our novel mouse model introduces combinatorial poln and poll knockouts into an SKH1/hairless $x^{-1-}$ background. These mice are nucleotide excision repair (NER)deficient and develop tumors after only 8 weeks of UV irradiation. Using established models of UV- and chemically-induced skin cancer, we will be able to identify any previously unobserved effects of poll deficiency alone and in combination with poln deficiency during skin tumorigenesis. We will characterize the DNA damage and apoptotic response of epidermal cells in order to identify changes in these characteristics 
due to proposed tumor suppression by poll. Finally, we will directly test the somatic mutation hypothesis of cancer by comparing in vitro mutagenesis results from Chapter 2 with in vivo carcinogenesis results.

\section{Mutation and Cancer}

Mutagenesis is a recognized cornerstone of every form of human cancer $\left[{ }^{1,28}\right]$ dating back to the discovery of aneuploidy in cancer cells $\left[{ }^{12}\right]$. According to the modern somatic mutation hypothesis of cancer, a cell must undergo several independent genetic and epigenetic events that together confer properties associated with the malignant phenotype. These include acquisition of infinite lifespan, resistance to apoptotic signals, growth factor independence, resistance to antigrowth signals, angiogenesis, and tissue invasion $\left[{ }^{32}\right]$. Acknowledgment of the critical role of mutations in carcinogenesis opens the possibility of chemoprevention using antimutator strategies. Although recent advances have elucidated key details of the pathways underlying mutagenesis, there exist critical gaps in our knowledge of the fundamental mechanisms by which DNA is mutated during carcinogenesis. In this thesis, we will investigate how environmental carcinogens permanently alter the sequence of DNA in order to cause cancer.

\section{Translesion Synthesis in Eukaryotes}

Recent evidence implicates DNA polymerase episilon $(\varepsilon)$ in leading strand DNA replication, and delta $(\delta)$ in lagging strand $\left[{ }^{65}\right]$. When these enzymes encounter adducts that distort the helix, a variety of bypass mechanisms are initiated. This is particularly true of adducts in the leading strand template. The signals that initiate these responses are poorly understood at the present time, and constitute active areas of investigation in many laboratories including our own. It has been shown using a plasmid containing a site-specific acetylaminofluorene adduct that error-free damage avoidance accounts for more than $92 \%$ of lesion bypass, and that mutagenic translesion synthesis accounts for only $0.3 \%$ of bypass events $\left[{ }^{4}\right]$. It is clear from these studies that error-free homologous 
recombination is the preferred method to resolve blocked replication forks in $S$. cerevisiae, and experts in the field generally agree that these mechanisms are conserved in higher eukaryotic cells. Nevertheless, direct DNA synthesis past the lesion clearly occurs in all cells, and is the source of virtually all mutations induced by genotoxic carcinogens. This process is called translesion synthesis (TLS) and involves recruitment of Y-family DNA polymerases. The signaling cascade that initiates TLS is poorly understood. Data indicate that monoubiquitination of PCNA on K174 of each subunit is an early event that appears to promote interaction with REV1 and poln in yeast. This is also true of higher eukaryotic cells, but such cells have additional layers of complexity because they have two additional homologues (POLI and POLK) that are not present in yeast. The cell biology associated with these enzymes, which presumably act in concert with REV1 and poln, is the subject of this thesis. 


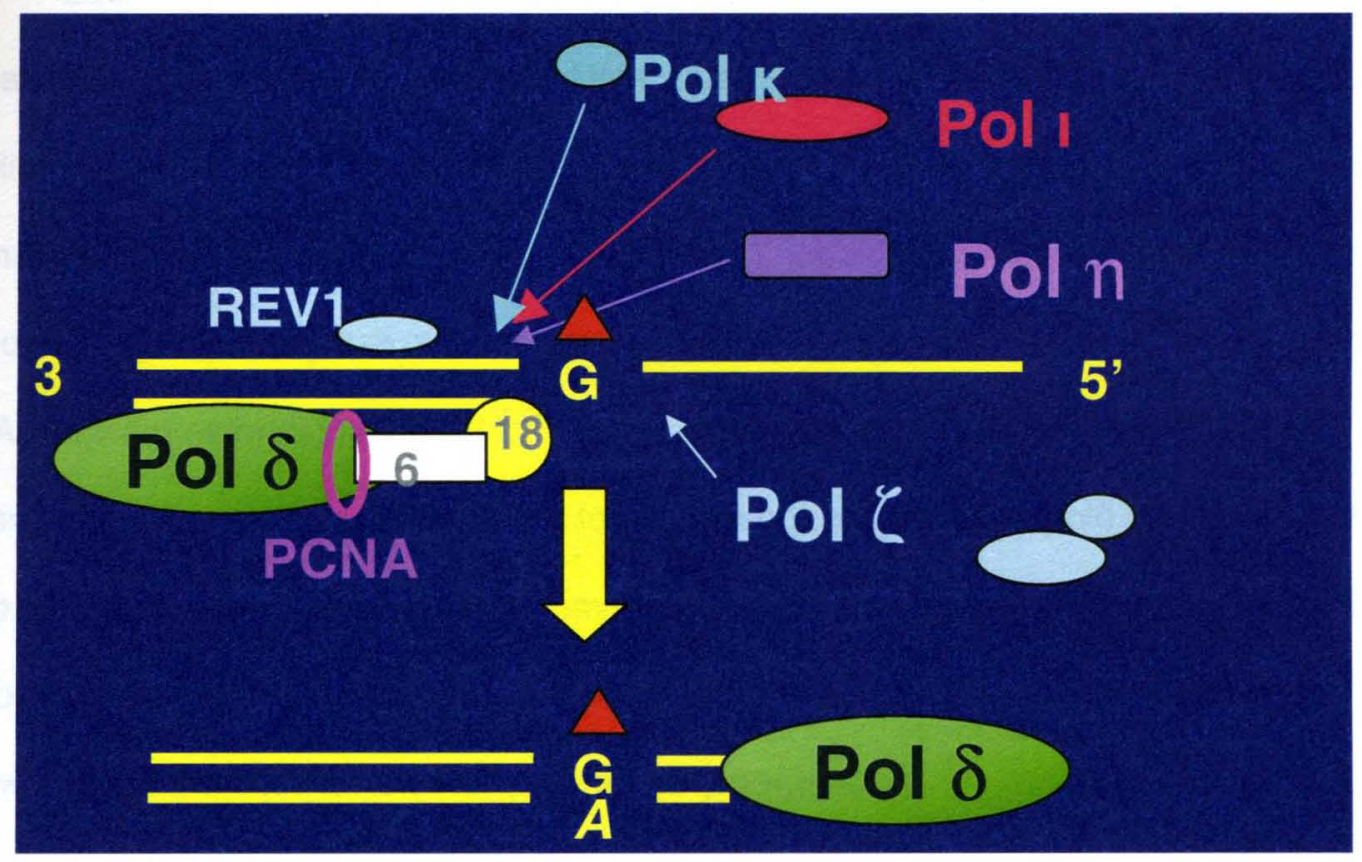

Figure 1.1. Model for translesion synthesis. DNA damage causes arrest of the replication fork and recruitment of RAD6/RAD18 and REV1. Monoubiquitination of PCNA facilitates recruitment of poln, polı, or polk to synthesize 1-2 nt directly past the lesion. Extension by polろ leaves a suitable primer template for continued replication by polठ or pole. 
Each of the Y-family enzymes is characterized by an open active site that is capable of accommodating damaged DNA, but the costs of this unique capacity are fidelity and processivity $\left[{ }^{59}\right]$. REV1 is required for TLS in eukaryotes $\left[{ }^{30 ; 40}\right]$, but appears to primarily play a structural role in recruiting other $Y$-family polymerases to actively bypass the damage $\left[{ }^{54 ; 82}\right]$. Only $1-2 \mathrm{nt}$ are inserted by poln, $\mathrm{l}$, or $\mathrm{k}$ before they dissociate from the DNA, allowing extension by polక $\left[^{37 ; 55}\right]$, another critical TLS polymerase $\left[{ }^{40 ; 51}\right]$. This extended primer terminus is sufficient for continued replication by polठ or $\varepsilon$. Although in vitro studies using purified enzymes have addressed the kinetics of bypassing specific lesions by individual polymerases, we designed this project to fill critical gaps in our knowledge of the cellular roles of Y-family polymerases.

The most striking role for TLS in humans is in xeroderma pigmentosum variant (XPV) syndrome. XP patients are extremely prone to UV-induced skin cancer because cells from most patients are deficient in proteins of the nucleotide excision repair (NER) pathway, which is responsible for recognizing and removing structurally diverse adducts that distort the DNA helix. However, cells from a subset of XP patients were found to be NER-proficient, despite the fact that the individuals displayed the classical XP phenotype $\left[{ }^{49 ; 73}\right]$. These patients were found to be deficient in DNA polymerase $n\left[{ }^{35 ; 44}\right]$ and theirs are the most hypermutable known human cells in response to UV, despite the fact that NER actively repairs UV damage comparably to wild-type cells[ $\left.{ }^{77}\right]$. In vitro studies revealed that POL $\eta$ replicates TT cyclobutane pyrimidine dimers, the most frequent lesions induced by UV, as faithfully as an undamaged TT template $\left[{ }^{36 ; 4344}\right]$. Hence, lack of POL $\eta$ results in TLS past UV-induced lesions by more error-prone polymerases. Recently developed knockout mouse models have been used to examine the in vivo role of poln and poll in response to chronic UV exposure. $\mathrm{pol}^{-/ /} \mathrm{poli}^{+/+}$mice were extremely susceptible to UV-induced skin cancer and their cells displayed a similar hypermutable phenotype to their human counterparts, validating the mouse model of 
$\mathrm{XPV}\left[{ }^{27 ; 58}\right]$. Our group showed that fibroblasts from poll $^{-1 /}$ poll $^{-1-}$ mice showed decreased UV-induced mutation frequency; however, these mice developed tumors about twice as fast as poll $\eta^{-/-}$pollt/+ mice $\left[{ }^{27}\right]$. Deficiency in poll was also required for metastases and was associated with increased tumor burden $\left[{ }^{58}\right]$. These data suggest a role for polı as a tumor suppressor that is separate from its mechanism as a mutagenic polymerase, since deficiency in the enzyme decreased mutation frequency and yet increased tumor development and tumor burden. We will investigate the tumor suppressor role of polı in this project.

\section{Recruitment of Y-Family Polymerases}

Previous reports showed that while $P O L \eta$ deficiency in human cells drastically increased the UV-induced mutation frequency, no effect was seen on mutagenesis induced by benzo[a]pyrene-7,8-diol-9,10-epoxide (BPDE) $\left[{ }^{78}\right]$. In contrast, recent studies by our group have shown that BPDE-induced mutation frequency is decreased in POL $\eta^{-1-}$ human and murine fibroblasts (see References). These results are consistent with reports of error-prone bypass of BPDE damage using purified poln $\left[{ }^{87: 88 ; 92}\right]$. Along with the novel finding that poln acts in error-free bypass of UV damage and error-prone bypass of bulky BPDE lesions in live mammalian cells, our results suggest that the recruitment of $Y$-family polymerases to stalled replication fork is not dependent upon the lesion. Rather, we hypothesize that poln is the primary TLS polymerase and is recruited to stalled replication forks first, and in its absence polı or polk would be allowed greater access to the lesion. We will examine this hypothesis in Chapter 2 using knockout models of poln and polı in response to treatment with chemically distinct genotoxicants.

\section{DNA Damage and Cell Cycle Checkpoints}

Environmental carcinogens such as benzo[a]pyrene, aminofluorene, and nitropyrene are metabolically activated and bind to DNA forming bulky, helix-distorting lesions $[; ; 722 ; 63 ; 72]$. These adducts are recognized and removed by nucleotide excision 
repair $\left[{ }^{17 ; 18 ; 47 ; 48}\right]$. However, if these adducts remain in the DNA when the cell enters Sphase they pose a significant threat to genomic integrity: the DNA replication complex cannot replicate past such adducts in the template. Although the proximal signals are poorly understood at the present time, stalled replication forks activate cell cycle checkpoints, presumably to allow removal of the adducts. Checkpoints are complex signal transduction pathways that block cell cycle progression in response to DNA damage $\left[{ }^{93}\right]$. These pathways exist for $G_{1}, S, G_{2}$ and $M$ phases to manage potential DNA damage throughout the cell cycle; the intra-S checkpoint is most relevant to this thesis. The molecular mechanisms underlying the activation of this checkpoint are not well understood. Available data indicate that stalled replication forks initiate the S-phase checkpoint by recruitment of the protein kinase ATR, and to a lesser extent the related protein ATM. ATR recruitment is dependent on a structural protein (ATR interacting protein) and may be initiated by extensive regions of single stranded DNA coated by RPA $\left[{ }^{95 ; 96}\right]$. The downstream targets of phosphorylation by ATR/ATM are myriad, and in this context are thought to promote degradation of cofactors that are required for progression through S-phase.

It is of interest that bulky adducts induced by BPDE elicit an S-phase checkpoint in human lung carcinoma cells $\left[{ }^{31 ; 79}\right]$ that is dependent upon the $\mathrm{Y}$-family polymerase $\mathrm{K}$. A deficiency in this polymerase results in failure to recover from BPDE-induced S-phase arrest and causes double strand breaks, likely due to collapse of stalled replication forks $\left[{ }^{10}\right]$. This is the first direct evidence of cellular requirement for a translesion synthesis polymerase for cell cycle regulation, and supports the hypothesis that such polymerases are implicated in the activation of the intra-S-phase checkpoint. This hypothesis is strengthened by a recent report that human cells with significantly reduced expression of $R E V 7$ showed a decreased rate of S-phase progression after UV irradiation $\left.{ }^{50}\right]$. REV7 is the non-catalytic partner of REV3 in the B-family polymerase 
POL $\zeta$, the first discovered TLS polymerase $\left[{ }^{56}\right]$. In Chapter 3, we propose to examine the hypothesis that the tumor suppressor function of polı is due to a similar function of this polymerase in activating cell cycle checkpoints.

\section{miRNA and Cancer}

miRNA are 20-22 base RNAs which negatively regulate gene expression by destabilizing target mRNAs. Initial transcription of miRNA genes yields larger primary miRNAs (pri-miRNAs) which are cropped by nuclear enzymes into $\sim 65 \mathrm{nt}$ hairpin-shaped precursors (pre-miRNAs). Pre-miRNAs are exported into the cytoplasm, where further processing yields a 22 nt duplex which complexes with the miRNA-induced silencing complex (miRISC). This complex can target other transcripts for degradation through perfect sequence complementarity in the 3' UTR of the target or, likely more common in animals, repress translation of targeted transcripts through indirect complementarity $\left[{ }^{3 ; 14}\right]$. miRNA gene expression patterns are greatly altered in many cancers, and several miRNAs are known to target oncogenes or tumor promoters (reviewed in $\left[{ }^{86}\right]$ ), making them strong candidates for cancer studies. It has been shown by our collaborators that the ubiquitous carcinogen BPDE alters miRNA gene expression profiles in small airway epithelial cells (unpublished observations). We hypothesize that polı status will alter miRNA gene expression changes induced by other carcinogens, including UV, and that these changes will provide insight as to the pathways effected by poll proficiency.

\section{Skin Cancer as a Tumorigenesis Model}

More than one million new cases of nonmelanoma skin cancer (NMSC) will be diagnosed in the U.S. in 2007, making it the most commonly diagnosed cancer in the country (American Cancer Society 2007 Facts and Figures). Ultraviolet radiation is the most ubiquitous carcinogen in the environment and is the primary etiological agent causing NMSC. Carcinogenesis from environmental UV exposure can be attributed to radiation ranging from $280-320 \mathrm{~nm}$ in wavelength (UVB), which generates 
photoproducts in DNA capable of causing mutations. Short-wave UV (UVC) ranges from $100-280 \mathrm{~nm}$ and is also highly carcinogenic, but is filtered out completely by atmospheric ozone and is thus not environmentally relevant. UVA is characterized by wavelengths between $320-400 \mathrm{~nm}$ and is only carcinogenic at much higher doses in mice compared to UVB due to absorption by cellular chromophores other than DNA and principle production of reactive oxygen species $\left[{ }^{9 ; 52}\right]$. Ultraviolet radiation produces measurable effects in human and mouse skin. Trp53 is frequently mutated in UVinduced mouse and human skin cancers $\left[{ }^{13 ; 53}\right]$, and this mutated tumor suppressor causes formation of precancerous clones in irradiated $\operatorname{skin}\left[{ }^{8 ; 38}\right]$. UV also induces a well characterized apoptotic sunburn response which appears to require wild type trp53.

Sunburn cells are characterized by pycnotic nuclei and intensely eosinophilic cytoplasm, as well as DNA strand breaks $\left[{ }^{94}\right]$. We hypothesize that polı promotes $\mathrm{p} 53$ accumulation, cell cycle arrest, and apoptosis in its role as a tumor suppressor.

Xeroderma pigmentosum (XP) has been described as a syndrome characterized by extreme predisposition to UV-induced skin cancer. The majority of patients have dysfunctional NER, resulting in faulty recognition and repair of helix distorting lesions including 6-4 photoproducts and cyclobutane pyrimidine dimers (CPD) induced by UV. Patients from XP complementation group $A$ display the most severe phenotype, including extreme photosensitivity and neurological defects, and typically die of metastatic skin cancer early in life. Hairless mice that are homozygous $\mathrm{xpa}^{-{ }^{-}}$, developed by Harry van Steeg, display a similar phenotype and are extremely susceptible to UV carcinogenesis $\left[{ }^{19}\right]$ with a tumor latency of $\sim 10$ weeks as compared to $\sim 1$ year with Balb/c mice $\left(\left[{ }^{27}\right]\right.$ and unpublished observations). The van Steeg mice represent an excellent and well studied skin cancer model $[19 ; 21 ; 26 ; 66 ; 74 ; 75]$ and will be used in this thesis.

Benzo[a]pyrene $(\mathrm{B}[\mathrm{a}] \mathrm{P})$ is also a well studied skin carcinogen. It is clear that benzo[a]pyrene-7,8-diol-9,10-epoxide (BPDE), a metabolic derivative of $\mathrm{B}[\mathrm{a}] \mathrm{P}$, is the 
ultimate carcinogen $\left[{ }^{11 ; 71}\right]$. BPDE formation proceeds through the action of CYP450, microsomal epoxide hydratase, and repeated CYP450 oxidation (reviewed in $\left[{ }^{62}\right]$ ). Carcinogenic activity of $\mathrm{B}[\mathrm{a}] \mathrm{P}$ is primarily due to in vivo binding of the ultimate carcinogen to DNA to form bulky adducts $\left[{ }^{71}\right]$. As analyzed by ${ }^{32} \mathrm{P}$-postlabeling, stable BPDE- $N^{2}-d G$ adducts constitute over $98 \%$ of adducts formed in mouse skin treated with anti-BPDE $\left[{ }^{16}\right]$. These adducts are normally recognized and repaired by enzymes in the NER pathway, and the NER-deficient mice we propose to use have been shown to accumulate more BPDE:DNA adducts than wild-type mice after $\mathrm{B}[\mathrm{a}] \mathrm{P}$ treatment $\left[{ }^{20}\right]$. These mice are also more sensitive to $\mathrm{B}[\mathrm{a}] \mathrm{P}$-induced lung carcinogenesis $\left[{ }^{33}\right]$, and represent an excellent model for chemical carcinogenesis.

Acetylaminofluorene (AAF) is a well characterized model mutagen and liver, intestine, and urinary bladder carcinogen. AAF is subject to numerous metabolic activities in vivo that can result in formation of electrophilic intermediates capable of binding to DNA. N-and O-acetylation, hydroxylation, and sulfation all may lead to activation of the compound through many possible pathways $\left[^{5}\right]$. Three major adducts are formed by AAF in vitro and in vivo and serve as NER substrates. AAF-C8-dG and AF-C8-dG form at differing ratios depending on cell type and activity of microsomal deacetylase $\left[{ }^{63}\right]$. AF-N2-dG is formed as a minor but persistent adduct in vivo[ $\left.{ }^{80}\right]$ and is significantly less mutagenic than C8-dG adducts $\left[{ }^{84}\right]$. In mouse epidermal cells treated with the active metabolite $\mathrm{N}$-acetoxy-2-acetylaminofluorene (AAAF), AF-C8-dG adducts make up over $90 \%$ of DNA adducts formed $\left.{ }^{63}\right]$

\section{Significance}

Our studies support a role for mouse polı in mutagenic translesion synthesis and in tumor suppression after UV exposure. In addition, limited available evidence indicates there may be differences in $\mathrm{Y}$-family polymerase activities in response to $\mathrm{UV}$ and chemical damage. These areas represent critical gaps in our knowledge of mammalian 
mutagenesis. We hypothesize that DNA polymerase $\mathrm{I}$ acts as a mutagenic polymerase in translesion synthesis and as a tumor suppressor through a separate mechanism. We propose to investigate the cellular roles of $Y$-family polymerases in order to further understanding of the mechanism of carcinogenesis by environmental agents with the ultimate aim of preventing cancer caused by these agents. 


\section{CHAPTER 2}

\section{EVALUATE THE MUTAGENIC PROPERTIES OF CHEMICAL CARCINOGENS IN MAMMALIAN FIBROBLASTS DEFICIENT FOR Y-FAMILY POLYMERASES \\ INTRODUCTION}

In this Chapter we will compare the cytotoxic and mutagenic properties of BPDE and AAF. BPDE is the ultimate genotoxicant metabolized from the ubiquitous carcinogen benzo[a]pyrene and primarily forms $\mathrm{N}^{2}$-dG adducts $\left[{ }^{15 ; 69}\right]$. This carcinogen will be used in Chapter 4 for in vivo tumorigenesis studies. AAAF is the active metabolite of AAF and primarily adducts $\mathrm{C} 8$ of deoxyguanosine $\left[{ }^{57}\right]$. This Chapter will allow us to examine the hypothesis that structurally different chemical adducts have varying mutagenic activity when bypassed by Y-family polymerases. We will also directly test the somatic mutation hypothesis of cancer by correlating in vitro mutagenesis data with in vivo tumorigenesis data collected in Chapter 4. 


\section{MATERIALS AND METHODS}

\section{Cell lines to be used}

We used established NF1604, XP4BE, and XP115LO human cell lines as well as primary fibroblasts from knockout mice. NF1604 cells were isolated from normal fetal lung tissue, and XP4BE and XP115LO cells are from XP variant patients. All lines are stably transfected with a plasmid expressing human telomerase reverse transcriptase. This gives them an infinite lifespan, but they are otherwise normal[ $\left.{ }^{60}\right]$. poln knockout mice were recently generated by our collaborators in a C57Bl/6 hybrid background $\left.{ }^{42}\right]$. To generate pol $\eta^{--}$poli- double knockouts, these animals were bred with 129/Ola mice, which have been shown to carry a nonsense mutation in poll resulting in a protein truncated at Ser-27 $\left[{ }^{45}\right]$. Primary fibroblasts have been isolated from these mice and used for mutagenesis studies in our laboratory $\left[{ }^{27}\right]$, and these cells were used in this Chapter. Mouse fibroblasts were grown in monolayer cultures using a-MEM supplemented with non-essential amino acids, penicillin-streptomycin and $10 \%$ fetal bovine serum. They were maintained in exponential growth. We routinely grow primary murine cells in a $3 \% \mathrm{O}_{2} / 5 \% \mathrm{CO}_{2} / 92 \% \mathrm{~N}_{2}$ atmosphere $\left[{ }^{61}\right]$.

\section{hprt mutagenesis}

For genotoxicant treatment, cells were plated at $1 \times 10^{4} \mathrm{~cm}^{-2}$. The culture media was removed and cells were washed twice with sterile phosphate-buffered saline (PBS, $\mathrm{pH}$ 7.4). Serum-free media was added to the cells along with each chemical carcinogen for a period of one hour. Doses of $0-250 \mathrm{nM}$ BPDE and 0 - 2.0 $\mu \mathrm{M}$ AAF were used for cytotoxicity studies. We used the dose giving $\sim 37 \%$ survival for mutagenesis studies. After one hour of treatment, the culture media was aspirated followed by two washes in PBS. For cytotoxicity, cells were trypsinized and counted, then replated at cloning density (the exact number depends on the expected survival). After two weeks, plates 
were stained with $1 \%$ crystal violet and counted. For mutagenesis, cells were maintained in exponential growth for eight days after treatment, after which we trypsinized, counted, and selected $1 \times 10^{6}$ cells with $40 \mu \mathrm{M} 6$-thioguanine at a density of $3000 \mathrm{~cm}^{-2}$. After 2 weeks of selection, we isolated individual TG' clones, trypsinized, and resuspended them in RNase-free PBS. The technique for amplifying the hprt gene was performed as described $\left[{ }^{83}\right]$ with modifications routine in our laboratory $\left[{ }^{23}\right]$. Briefly, $T G^{r}$ colonies were pelleted at $4^{\circ} \mathrm{C}$ and the PBS removed. The cells were directly lysed and cDNA generated using a cDNA cocktail. After incubation at $37^{\circ} \mathrm{C}$ for $1 \mathrm{~h}$ amplification was performed using a Taq polymerase cocktail and two outer primers. The $5^{\prime}$ primer is from position -47 to -28 relative to the start codon (GGC TTC CTC CTC AGA CCG CT). The 3' primer is from position 790 to 771 (ACA TCA ACA GGA CTC CTC GT). Reamplification using an inner primer set ( 5 ', from -27 to -8 , TTT TGC CGC GAG CCG ACC GG and 3', from 770 to 751 , ATT TGC AGA TTC AAC TTG CG) will follow. The PCR products were sequenced with each of the inner primers using an $A B I 370$ automated DNA sequencer and dRhodamine dye terminator chemistry. 


\section{RESULTS}

\section{BPDE in Human Fibroblasts}

We treated POL $\eta^{-1-}$ XP115LO and wild type NF1604 human fibroblasts with 150 or $200 \mathrm{nM}$ BPDE and measured clonogenic survival and mutagenesis. These cells are isolated from an XP variant patient (XP115Lo) and normal fetal lung (NF1604) and are stably transfected with a plasmid expressing human telomerase reverse transcriptase. This gives them infinite lifespan, but they are otherwise normal[ $[6 ; 76]$. After treatment and eight days of expression, cells were selected with 6-thioguanine (TG). Table 1 shows that $\mathrm{XP}$ variant fibroblasts are moderately sensitive to killing by BPDE, which is similar to the phenotype displayed by XP variant cells in response to UV $\left[{ }^{49}\right]$. However, unlike XPV cells after UV irradiation, XP115LO fibroblasts showed decreased mutation frequencies when compared to wild type NF1604 fibroblasts (Table 1). This novel result has been reproduced over three experiments using these cells and is consistent with published reports of in vitro error-prone TLS by purified human POLn past BPDE-N²-dG DNA adducts $\left[{ }^{87 ; 88 ; 92}\right]$. Our results indicating POL $\eta$ in error-prone TLS of BPDE lesions contrasts with the known role of POLn in error-free TLS past UV-induced lesions. Our conclusion that POL $\eta$ acts in error-prone bypass of BPDE lesions is also in sharp contrast with a report that POL $\eta$ is unresponsive to BPDE lesions in human $P O L \eta^{-1-}$ XP4BE cells $\left[{ }^{77}\right]$. We amplified and sequenced the HPRT gene from mutant colonies and found very little difference in the mutation spectrum, e.g. the types of mutations induced, of wild type NF1604 and POL ${ }^{-/-}$XP115LO fibroblasts (Table 2). The similarity in BPDEinduced base substitution indicates that the enzyme acting to bypass the BPDE lesion in the absence of POLn has a similar mutation spectrum for this adduct. 


\section{BPDE in Murine Fibroblasts}

To extend the results we obtained from studies of human cells, we performed similar experiments with primary murine fibroblasts deficient for poln, poli, or both. We first compared the sensitivity to BPDE of the cells using in situ cytotoxicity tests. For this method, cells were plated at cloning density and treated with varying doses of BPDE. Figure 2.1 displays the results of one experiment which show no apparent differences in the cytotoxicity of BPDE among the four cell lines, although significant sensitivity of pol $\eta^{-}$ " poli ${ }^{-1}$ double knockout cells may be shown after experimental replication. The dose resulting in $37 \%$ survival $\left(D_{37}\right)$ for each cell line was $\sim 100 \mathrm{nM}$. It is known from unpublished observations that mouse primary fibroblasts are more sensitive to genotoxicant treatments at low densities. It is for this reason that further cytotoxicity studies are performed by treating cells at $1 \times 10^{4}$ cells $/ \mathrm{cm}^{2}$ and immediately replating at cloning density. This method of replating cytotoxicity accurately reflects the survival of cells treated at equal density for mutagenesis. Figure 2.2 shows the results of one or two replating cytotoxicity studies using $150 \mathrm{nM}$ BPDE, the known $D_{37}$ of wild-type primary murine fibroblasts at replating density. As in Figure 2.1, there are no obvious differences in sensitivity to BPDE treatment with the possible exception of the double knockout cells. Significantly, we used heterozygous $\mathrm{poln}^{+/}$poll ${ }^{+/}$cells for experiments shown in Figures 2.2 and 2.3. These cells were provided by a collaborator as homozygous poln knockouts and were genotyped for confirmation of that only after these studies were completed. We have since verified by PCR all genotypes indicated in this thesis. Strikingly, haploinsufficiency for pol $\eta$ in these cells was sufficient to markedly reduce the mutation frequency induced by $150 \mathrm{nM}$ BPDE as shown in Figure

2.3. These results support our studies of human cells indicating POLn in error-prone bypass of BPDE DNA adducts in contrast to its role in error-free bypass of UV damage. Similarly, $p o l \eta^{+/+}$poli $r^{/ /}$fibroblasts showed drastically reduced mutation frequencies after 
BPDE treatment, and pol $\eta^{-1-}$ poli- cells exhibited a $98 \%$ reduction in hprt mutations induced by $150 \mathrm{nM}$ BPDE. These results reflect the findings of in vitro studies which have characterized the error-prone bypass of BPDE- $N^{2}-d G$ DNA adducts, the major adduct induced by this carcinogen, by purified POLn and POLI[ $\left.{ }^{67}\right]$. We hypothesize that the low mutation frequency of pol $^{-/-}$polir- double knockout murine cells is due to errorfree lesion bypass by polk, which has also been characterized in vitro $\left.{ }^{90 ; 91}\right]$.

\section{AAAF in Murine Fibroblasts}

We examined the cytotoxic effects of $\mathrm{N}$-acetoxy-2-acetylaminofluorene (AAAF) using replating cytotoxicity assays. This well characterized mutagen is a major metabolite of acetylaminofluorene, a carcinogen present in diesel exhaust, and predominantly forms AF-C8-dG adducts $\left[{ }^{63 ; 64}\right]$. This lesion is structurally distinct from the N2-dG adduct which predominates after BPDE treatment, and the differences in cytotoxicity of the two chemicals are readily apparent in Figure 2.4. As compared to the very similar sensitivities of these cells to treatment with BPDE, poln and/or polı deficient murine fibroblasts appear to be more sensitive to killing by AAAF. The $D_{37}$ calculated from these studies varies from $0.83 \mu \mathrm{M}$ for wild type cells to $0.16 \mu \mathrm{M}$ AAAF for pol $\eta^{-1}$ polit double knockout cells. This pattern of increased sensitivity is very similar to that characterized by our group after UV treatment of these cells $\left[{ }^{27}\right]$, and supports a role for these enzymes in prevention of replication fork collapse and double strand break cytotoxicity. We hypothesize based on in vitro studies of purified yeast poln $\left[{ }^{85}\right]$ and human POLI $\left[{ }^{89}\right]$ that poin acts in error-free bypass of AAAF-induced DNA damage, while polı participates in error-prone TLS of the lesion. We will investigate this lesion-specific fidelity of cellular poln and polı further in Chapter 4. 


\begin{tabular}{|l|l|c|c|c|}
\hline \multicolumn{2}{|c|}{ Experiment } & 1 & 2 & 3 \\
\hline \multicolumn{2}{|c|}{ BPDE Dose (nM) } & 150 & 150 & 200 \\
\hline \multirow{2}{*}{ Percent Survival } & 1604 & 73 & 62 & 33 \\
\cline { 2 - 5 } & XP115Lo & 53 & 55 & 21 \\
\hline Induced Mutants /10 & 1604 & 263 & 208 & 483 \\
\cline { 2 - 5 } Clonable Cells & XP115Lo & 53 & 85 & 104 \\
\cline { 2 - 5 } & & & & \\
\hline
\end{tabular}

Table 2.1. Cytotoxicity and mutagenesis of BPDE in human cells. Transformed human fibroblasts from normal (1604) or XP variant (XP115Lo) patients were treated with 150 or $200 \mathrm{nM}$ BPDE. XP115Lo cells appear to be slightly more sensitive to the treatment and are hypomutable. 


\begin{tabular}{|c|c|c|}
\hline & 1604 & XPV \\
\hline Transitions & 8.3 & $\begin{array}{ll}8.7 \\
\end{array}$ \\
\hline $\mathbf{G}>\mathbf{A}$ & 8.3 & 8.7 \\
\hline Transversions & 91.7 & 91.3 \\
\hline G>T & 58.3 & 69.6 \\
\hline $\mathrm{G}>\mathrm{C}$ & 8.3 & 17.4 \\
\hline$A>T$ & 25.0 & 4.3 \\
\hline
\end{tabular}

Table 2.2. BPDE-induced HPRT point mutations in human fibroblasts. Thioguanineresistant clones were isolated after BPDE treatment. HPRT mRNA was reverse transcribed and amplified by PCR for sequencing. Numbers represent percentage of total point mutations. 


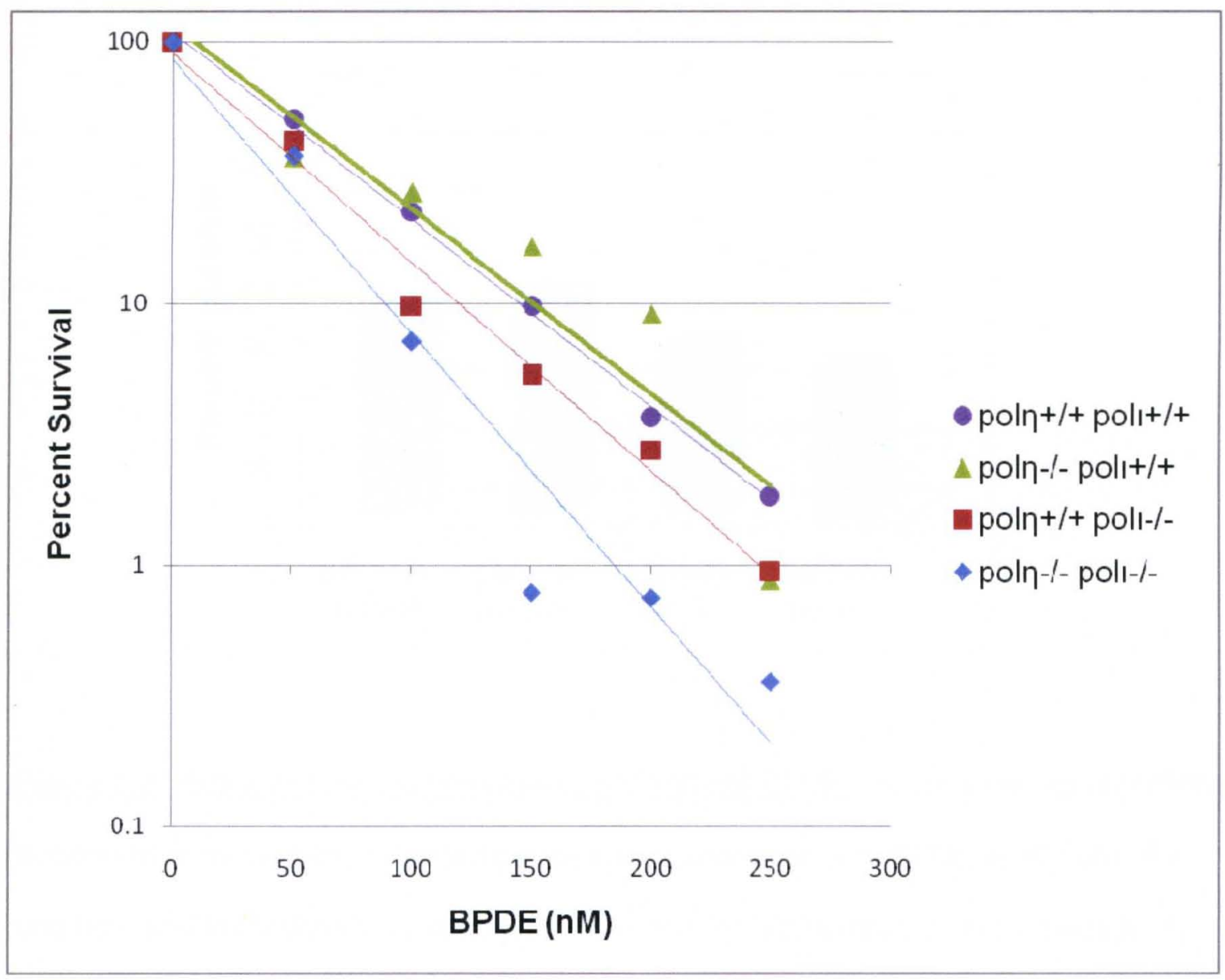

Figure 2.1. Survival of murine fibroblasts after BPDE. Primary dermal fibroblasts isolated from mice of the indicated genotypes were treated with BPDE at cloning density and refed after one week. After two weeks, colonies were stained with crystal violet and counted to assay survival. It should be noted that these cells are more sensitive to chemical genotoxicants when treated at low density. 


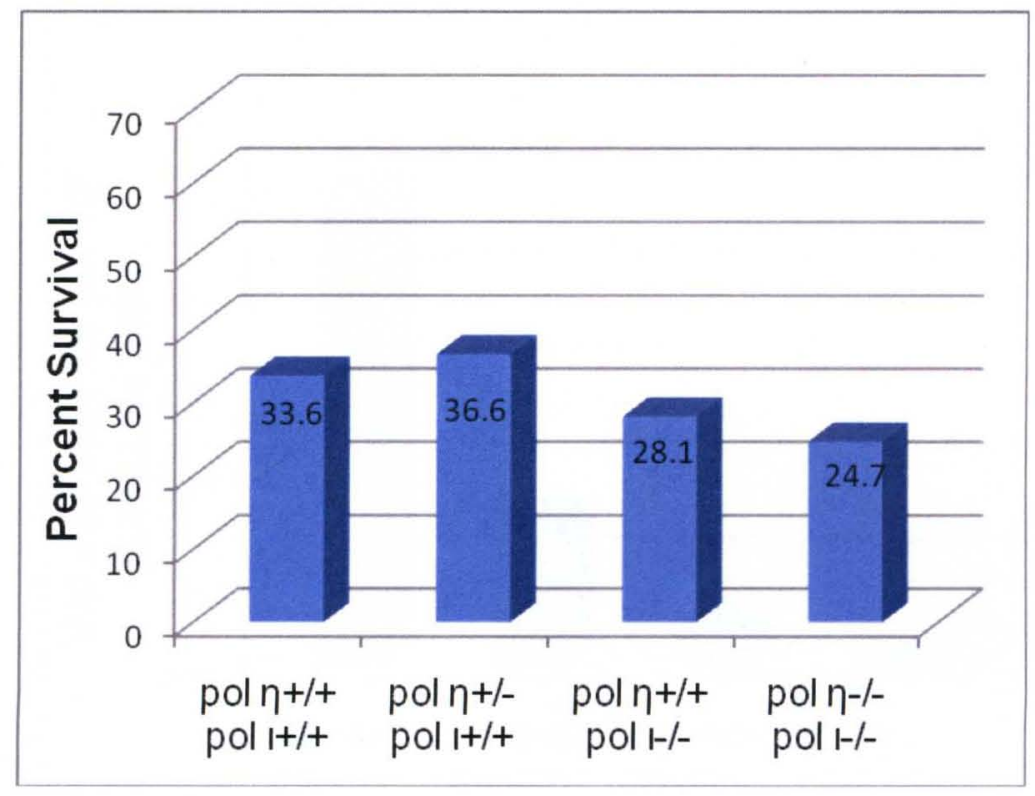

Figure 2.2. Suvival of murine fibroblasts after $150 \mathrm{nM} \mathrm{BPDE}$. Primary dermal fibroblasts isolated from mice of the indicated genotypes were treated with BPDE at $10^{-4} \mathrm{~cm}^{-2}$ for one hour and immediately replated at cloning density. Note that a poln heterozygote was used. 


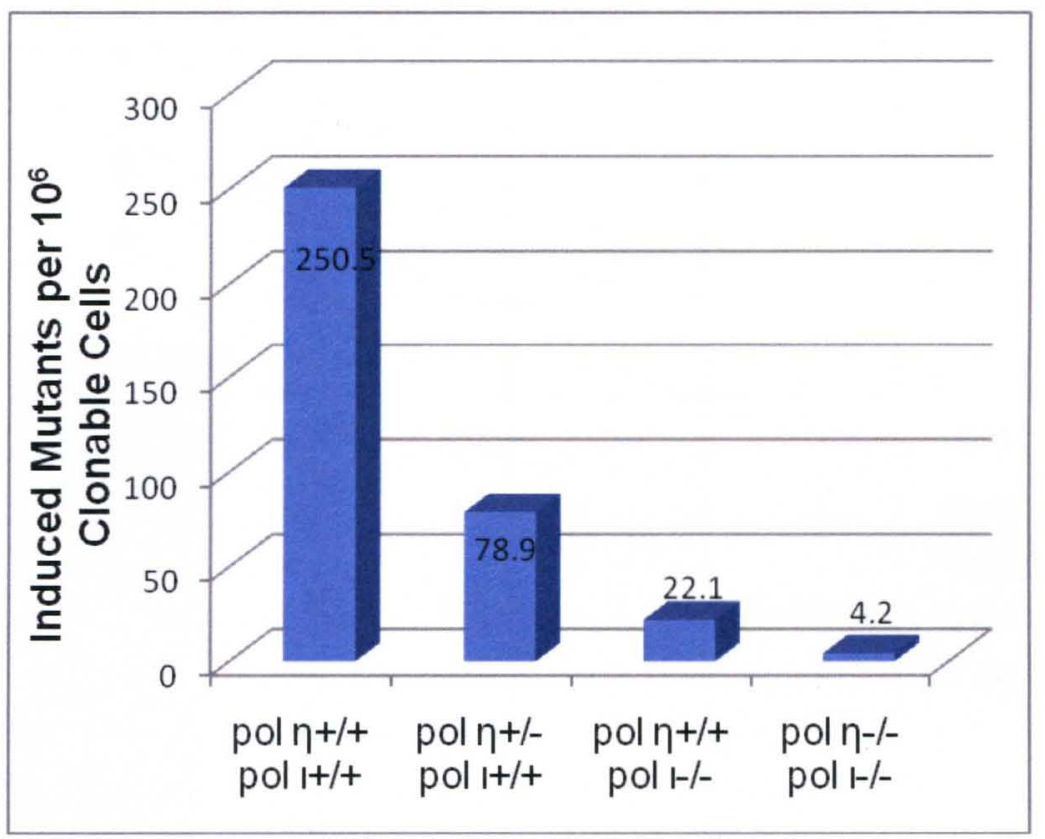

Figure 2.3. Mutagenesis after $150 \mathrm{nM} \mathrm{BPDE}$. Primary dermal fibroblasts isolated from mice of the indicated genotypes were treated with $150 \mathrm{nM}$ BPDE at $10^{4} \mathrm{~cm}^{-2}$. After eight days of exponential growth, cells were replated in $40 \mu \mathrm{M}$ 6-thioguanine and grown for two weeks. Thioguanine-resistant clones were stained with crystal violet. Note that a poln heterozygote was used. 


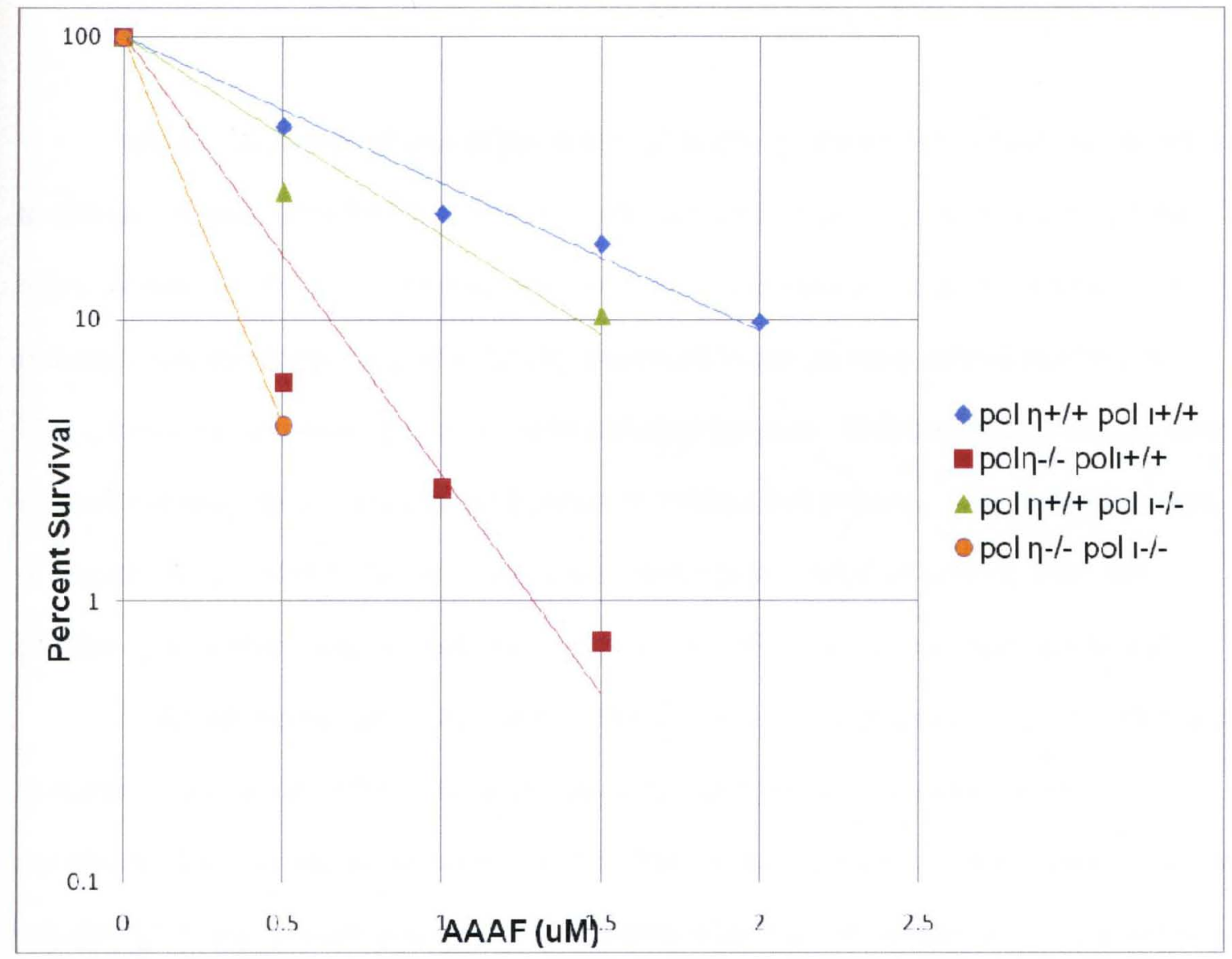

Figure 2.4. Cytotoxicity of AAAF in murine fibroblasts. Primary dermal fibroblasts isolated from mice of the indicated genotypes were treated with AAAF at $10^{4} \mathrm{~cm}^{-2}$ for one hour and immediately replated at cloning density. Cells were refed after one week and stained with crystal violet after two weeks. 


\section{CONCLUSIONS AND FUTURE DIRECTIONS}

We conclude from these initial data that neither poln nor polı is likely to contribute to cellular survival after BPDE treatment, although loss of poln appears to make cells more sensitive to AAAF. Strikingly, we found that both poln and poll deficiency caused reduced mutation frequency after BPDE treatment in our primary dermal fibroblasts. This effect was also seen in human cells deficient for poln. This supports a role for both enzymes in error-prone, mutagenic bypass of BPDE:DNA lesions. This is confirmation of results using purified poln and polı, but in contrast to published reports that poln deficiency in human cells causes no change on BPDE-induced mutation frequency[ $\left.{ }^{77}\right]$.

AAAF causes structurally distinct DNA lesions and appears to be more cytotoxic to murine cells deficient for poln. polı status did not appear to modulate AAAF sensitivity. These results are similar to the effect of deficiency for these enzymes on UV sensitivity $\left[{ }^{27}\right]$, and we will investigate mutagenesis by this carcinogen at the hprt locus as we have for BPDE. We hypothesize based on in vitro experiments $\left[{ }^{85 ; 89}\right]$ that poln participates in error-free bypass of AAAF damage and that polı is active in error-prone bypass of these lesions, again similar to the known roles of these enzymes in UV damage bypass[ $\left.{ }^{27}\right]$. 


\section{CHAPTER 3}

\section{INVESTIGATE THE TUMOR SUPPRESSOR ROLE OF MURINE POL IOTA INTRODUCTION}

We have shown that poll deficiency in a pol $\eta^{-/-}$background causes decreased UV-induced mutation frequency and decreased UV-induced tumor latency $\left[{ }^{27}\right]$, indicating a possible tumor suppressor role for the enzyme. It has been shown that polk ${ }^{-/ 2}$ mouse fibroblasts arrest in S-phase and display increased checkpoint signaling after treatment with BPDE and that recovery from this checkpoint is dependent upon polk. We propose to investigate the tumor suppressor role of poli in this Chapter, specifically focusing on cell cycle checkpoint signaling. We will also investigate differential miRNA and global gene expression responses to UV damage to determine the regulation of other genes and pathways by polı. 


\section{MATERIALS AND METHODS}

\section{Irradiation protocol}

Cells were plated at cloning density (the exact number depends upon the expected survival) or $1 \times 10^{4} \mathrm{~cm}^{-2}$ and allowed to attach overnight. The culture medium was then be aspirated and cells will be exposed to $1-20 \mathrm{~J} / \mathrm{m}^{-2}$ UVC. Culture medium was immediately replaced and cells were refed at one week and stained for counting and cytotoxicity determination at two weeks or harvested at various time points for analyses detailed below.

\section{Global gene expression}

In order to identify potential effects of polı expression on a larger scale, we examined the effects on global gene expression due to loss of poln, poll, or both in primary murine fibroblasts. This experiment was designed to discover the effect of poli deficiency on the expression of genes in known tumor suppressor or promoter pathways. Cells were irradiated with $20 \mathrm{Jcm}^{-2}$ at $1 \times 10^{4} \mathrm{~cm}^{-2}$ and total RNA was extracted using the Qiagen miRNeasy kit. After amplification, resultant cDNA was transcribed using the GeneChip® IVT Labeling Kit for hybridization on Affymetrix MOE 430_2.0 arrays using a GeneChip® Scanner 3000 7G. Statistical analysis (ANOVA) of the microarray data was performed to evaluate significant changes between the groups with a q-Value $<0.05$ using FDR (False Discovery Rate) multiple testing correction and Partek 6.1 software. We examined expression patterns associated with UV treatment, as well as differences in UV response between all cell lines. We randomly verified results using quantitative real-time PCR and Western Blots for affected proteins.

\section{miRNA microarrays}

To investigate the effect of poll deficiency on cancer-regulating miRNA expression, we analyzed global miRNA gene expression using a microarray-based 
assay (LC Sciences). Total RNA samples isolated before and after UV treatment were enriched for miRNA, labeled with Cy3 or Cy5, and hybridized to a dual-color microarray chip. For this technique, the relative abundance of each miRNA in each sample was analyzed by the proportion of Cy3/Cy5 fluorescence at each probe site on the chip. Each chip contains six redundant probes for each of the known 568 mature mouse miRNAs. After background subtraction and data normalization, statistical correlation between the three chips representing independent biological replicates identified any miRNA genes altered between groups. As above, we analyzed data for UV-responsive miRNA and differences in UV response between cell lines. Results were randomly validated using Northern Blots and RT-PCR. 


\section{RESULTS}

To determine the potential mechanism by which polı acts as a tumor suppressor in mammalian cells, we examined UV-induced changes in global gene expression in pol $\eta^{-/-}$poll $^{+/+}$and poln ${ }^{-1-}$ polli- primary murine fibroblasts. Our group previously showed that poln $\eta^{--}$poli- fibroblasts get fewer mutations after UV exposure, but mice with this genotype have a decreased UV-induced tumor latency compared to the XPV model poln ${ }^{-/-}$poli ${ }^{+/+}$mice $\left[{ }^{27}\right]$. To examine the effect of poll deficiency on global gene expression, we plated cells at $1 \times 10^{4} \mathrm{~cm}^{-2} 24 \mathrm{hr}$ before treatment with $4 \mathrm{Jm}^{-2} \mathrm{UVC}$. mRNA was isolated $24 \mathrm{hr}$ after treatment, reverse transcribed into cDNA and amplified for global

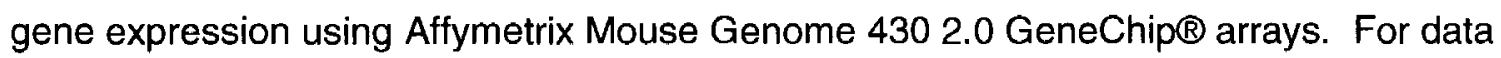
analysis, we used a 2-way ANOVA incorporating cell line and treatment as well as their interaction as factors. The resulting $p$-Values were false discovery rate (FDR) corrected and cut off at a corresponding q-value of 0.05 . Table 3 shows the 19 genes whose expression was modulated in different ways by treatment with UV between pol $^{-1}$ poll ${ }^{+/+}$ and $p o l \eta^{-1-}$ poll $^{-1-}$ cells. For example, protein tyrosine phosphatase receptor type $\mathrm{V}$ (ptprv) was the gene that showed the most statistically significant differential expression in the cell lines after UV exposure. In pol $\eta^{-/-}$poll $^{+/+}$cells, UV induced a 1.56-fold upregulation of ptprv, while a 5.67-fold UV-induced upregulation was observed in pol $\eta^{-/-}$poli- cells. This gene has only recently been characterized $\left[{ }^{41}\right]$, but has already been linked to p53 signaling, cell cycle checkpoints, and tumor suppression $\left[{ }^{24 ; 25}\right]$. ADAM8 (A Disintegrin And Metalloprotease 8) has been shown to be a possible diagnostic marker for lung cancer and renal cell carcinoma in humans $\left[{ }^{34 ; 68}\right]$ and is negatively correlated with prognosis in prostate, renal cell, and brain cancers $\left[{ }^{29 ; 81}\right]$. Also relevant to this project is cdc20, which promotes progression through and exit from $\mathrm{M}$ phase and is often 
overexpressed in malignancies $\left[{ }^{2 ; 39}\right]$. These genes will provide an important basis for the investigation of the tumor suppressor role of polı.

We also examined the effects of UV treatment on miRNA expression in these cells. Total RNA isolated after the treatment described above was enriched for miRNA and labeled with Cy3 or Cy5. Samples were hybridized in oppositely labeled pairs to two identical dual-color microarray chips containing probes for the 568 known mature miRNAs from the Sanger Database v10.0. Figure 3.1 shows results after background subtraction and data normalization. Expression of the miRNA listed was modulated after UV treatment. To our knowledge, this is the first evidence of altered miRNA expression after UV radiation in mammals. Using bioinformatics tools including the Sanger miRNA database for target mRNA prediction, we will be able to correlate miRNA expression data from all four cell lines to discover commonly affected tumor suppressor and promoter pathways altered by polı deficiency. 


\begin{tabular}{|c|c|c|c|c|}
\hline Name & Description & $\begin{array}{c}\mathrm{P}- \\
\text { value }\end{array}$ & $\begin{array}{l}\text { Fold Change } \\
\left(\text { poln }^{-/-} \text {poll }^{+/+}\right)\end{array}$ & $\begin{array}{l}\text { Fold Change } \\
\left(\text { poln }^{-1} \text { poll }^{-1}\right)\end{array}$ \\
\hline PTPRV & $\begin{array}{l}\text { protein tyrosine phosphatase, } \\
\text { receptor type, } V \text { (pseudogene) }\end{array}$ & 0.010 & 1.56 & 5.674 \\
\hline ADAM8 & ADAM metallopeptidase domain 8 & 0.016 & -1.01 & 1.557 \\
\hline PMAIP1 & $\begin{array}{l}\text { phorbol-12-myristate-13-acetate- } \\
\text { induced protein } 1\end{array}$ & 0.018 & 2.21 & 24.246 \\
\hline KIF23 & kinesin family member 23 & 0.019 & 1.98 & 1.349 \\
\hline $\begin{array}{l}\text { SLC9A3R } \\
1\end{array}$ & $\begin{array}{l}\text { solute carrier family } 9 \\
\text { (sodium/hydrogen exchanger), } \\
\text { member } 3 \text { regulator } 1\end{array}$ & 0.022 & -1.18 & 1.229 \\
\hline ODZ3 & $\begin{array}{l}\text { odz, odd Oz/ten-m homolog } 3 \\
\text { (Drosophila) }\end{array}$ & 0.023 & -1.11 & -3.631 \\
\hline PRKG1 & $\begin{array}{l}\text { protein kinase, cGMP-dependent, } \\
\text { type I }\end{array}$ & 0.026 & -2.34 & -4.339 \\
\hline C8ORF4 & chromosome 8 open reading frame & 0.037 & 2.69 & 1.362 \\
\hline GSTO1 & glutathione S-transferase omega 1 & 0.041 & 1.33 & 1.091 \\
\hline CDC20 & $\begin{array}{l}\text { cell division cycle } 20 \text { homolog (S. } \\
\text { cerevisiae) }\end{array}$ & 0.041 & 1.78 & 1.422 \\
\hline $\mathrm{PC}$ & pyruvate carboxylase & 0.042 & 1.28 & 1.697 \\
\hline DGKA & diacylglycerol kinase, alpha $80 \mathrm{kDa}$ & 0.042 & 1.52 & 2.467 \\
\hline RAD54L & RAD54-like (S. cerevisiae) & 0.042 & 1.63 & 1.308 \\
\hline $\begin{array}{l}\text { SLC9A3R } \\
2\end{array}$ & $\begin{array}{l}\text { solute carrier family } 9 \\
\text { (sodium/hydrogen exchanger), } \\
\text { member } 3 \text { regulator } 2\end{array}$ & 0.044 & -1.03 & 1.433 \\
\hline CRYAB & crystallin, alpha B & 0.045 & 2.80 & 1.678 \\
\hline EFS & embryonal Fyn-associated & 0.045 & 2.83 & 5.238 \\
\hline PAIP1 & $\begin{array}{l}\text { poly }(\mathrm{A}) \text { binding protein interacting } \\
\text { protein } 1\end{array}$ & 0.048 & 1.30 & -1.255 \\
\hline KCNIP1 & Kv channel interacting protein 1 & 0.048 & -1.30 & -3.485 \\
\hline MAN1A1 & $\begin{array}{l}\text { mannosidase, alpha, class } 1 \mathrm{~A} \text {, } \\
\text { member } 1\end{array}$ & 0.050 & 1.12 & 1.398 \\
\hline
\end{tabular}

Table 3.1. Differentially regulated, UV-responsive transcripts in primary murine fibroblasts. Dermal fibroblasts were treated with $4 \mathrm{Jm}^{-2}$ and total RNA was isolated after $24 \mathrm{hr}$. Affymetrix Mouse Genome 4302.0 GeneChip arrays were used to quantify mRNA levels. UV-responsive mRNAs were identified using 2-way ANOVA incorporating cell genotype and treatment, as well as their interaction, as factors. The 19 genes shown here were differentially regulated by UV treatment between cells of the two genotypes. 


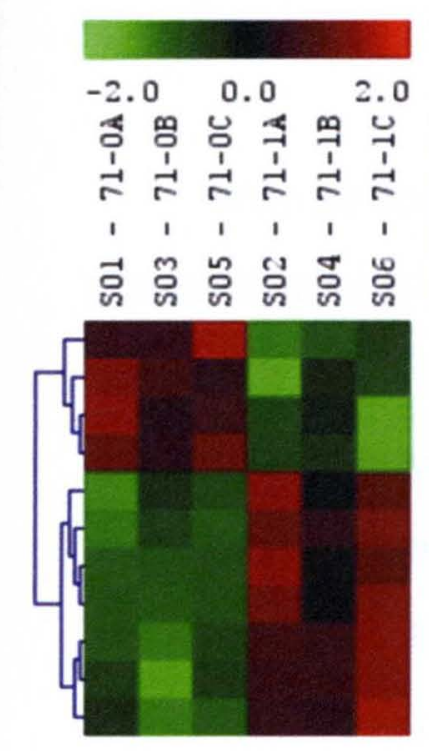

A.

poln ${ }^{-1-}$ polr $^{-1-}$

mmu-miR-495

mmu-miR-455

mul-miR-494

mmu-miR- 541

muu-miR-133b

mmu-miR-146b

mmu-miR-133 a

mul-miR-342-3p

mmu- 1 et $-7 i$

mmu-miR-34b-3p

mmu-miR-710

\section{p-value $<0.05$}
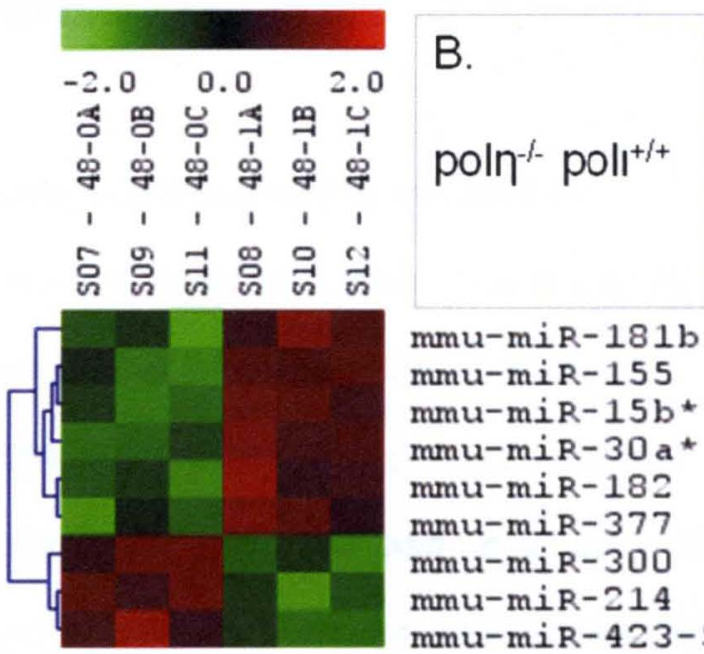

mmu-miR-181b

mu-miR-155

mmu-miR-15b*

mmu-miR-30a *

mul-miR-182

mmu-miR-377

mmu-miR-300

mmu-miR-214

mmu-miR-423-5p

p-value $<0.05$

Figure 3.1. UV-responsive miRNA. Primary dermal fibroblasts were treated with $4 \mathrm{Jm}^{-2}$ and total RNA was collected after $24 \mathrm{hr}$. After enrichment for small RNA, samples were labeled with either Сy3 or Cy5 and hybridized in oppositely labeled pairs to two identical dual-color microarray chips containing probes for mature murine miRNA from the Sanger Database v10.0. Two-way ANOVA was used to identify miRNAs with modulated expression after UV. 


\section{CONCLUSIONS AND FUTURE DIRECTIONS}

We have shown that UV radiation causes modulated mRNA and miRNA expression in our model system, primary dermal fibroblasts from mice. This is the first report of UV-responsive miRNA in mammalian cells. We have also shown that poll deficiency modulates both global gene and miRNA expression. We defined 19 genes

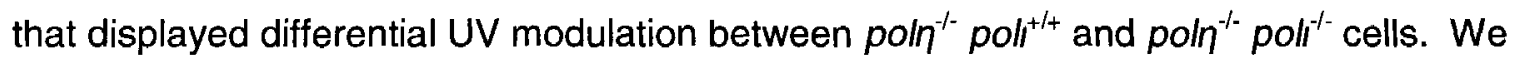
also defined mutually exclusive lists of nine and 11 miRNAs with modulated expression in poln $\eta^{-1-}$ poll $^{+/+}$and poln $\eta^{-1-}$ polit cells, respectively. The readily apparent differences in gene expression in these cells supports our hypothesis that poll could act as a tumor suppressor by modulating gene expression. To further investigate this hypothesis we will validate our initial results using QRT-PCR and western blotting for target protein levels.

In order to investigate cell cycle checkpoint activation after UV and the effects of poll deficiency, we will treat cells derived from mice deficient for poln, polı, or both with UV and utilize FACS analysis of cell cycle progression. We will also examine levels of checkpoint proteins and their phosphorylated epitopes via westen blot to detect activation of G1/S and G2/M checkpoints after UV treatment. These will include chk1 and chk2 along with phosphorylated epitopes chk1-phopho-Ser345 and chk2-phosphoThr68. We hypothesize that poll deficiency will promote cell cycle progression after UV damage, thereby promoting increased mutagenesis and/or chromosomal instability and promoting transformation of poll- cells. 


\section{CHAPTER 4}

\section{CHARACTERIZE THE EFFECT OF POL IOTA DEFICIENCY ON IN VIVO SKIN TUMORIGENESIS USING A NOVEL MOUSE MODEL \\ INTRODUCTION}

In this Chapter we propose to generate a novel mouse model for TLS-mediated UV- and B[a]P-induced skin cancer. This model is ideally suited for the hypothesis that polı acts as a tumor suppressor in vivo as we know that $100 \%$ of control SKH1/hairless $x p a^{-/-}$mice will develop tumors after UV and chemical treatment. We hypothesize that deficiency in polı will result in decreased tumor latency after UV irradiation and $\mathrm{B}[\mathrm{a}] \mathrm{P}$ carcinogenesis. Combined sunburn cell quantification and TUNEL assay will allow us to compare apoptosis in the epidermis of UV-irradiated mice. We hypothesize that poll deficiency will result in decreased levels of p53 and p21 activation and consequently decreased apoptosis, providing the basis for a tumor suppressor mechanism. We will also compare in vitro mutagenesis data using BPDE from Chapter 2 with data from the $\mathrm{B}[\mathrm{a}] \mathrm{P}$ tumorigenesis experiment outlined in this Chapter. This will allow us to directly test the somatic mutation hypothesis of cancer and investigate chemical-induced tumor suppression by poll. 


\section{MATERIALS AND METHODS}

\section{Mouse Model}

Previous studies used a combinatorial poln and poll knockout mouse model in a mixed $129 /$ Ola $X$ C57BV/6 background. This model is not ideal for UV carcinogenesis studies for two reasons. First, the mice must be shaved twice weekly for UV treatment. Second, neither wild type nor pol $\eta^{+/+}$poli $^{\gamma_{-}}$mice develop tumors after 20 weeks of UV treatment. For this reason, we are backcrossing these mice into an SKH1/hairless $x p a^{-/-}$ background. These mice were developed by Harry van Steeg and develop tumors after as few as 6 weeks of UV with an average latency of as little as 10 weeks $\left[{ }^{19}\right]$. The UVinduced cancer-prone phenotype of these mice will be an ideal background for elucidating the difference in skin cancer susceptibility between wild type and $p o l \eta^{+/+}$polit mice, which is critical for our hypothesis that polı acts as a tumor suppressor in vivo. To breed the mice, we back crossed C57Bl/6 poln ${ }^{-1}\left[{ }^{42}\right]$ and $129 \times 1 / \mathrm{SvJ}$ (JAX), which are naturally poll $^{-1-}\left[{ }^{45}\right]$, with SKH1/hairless $x p a^{-/-}$mice. We monitored the hairless $(h r)$ locus via screening for hairless pups at 4 weeks of age. We monitored $x p a\left[^{21}\right]$, poln $\left[^{42}\right]$, and poll $\left.{ }^{45}\right]$ using published PCR-based screens and genomic DNA from tail snips. All mice from generation F2 will be screened for $h r^{-/} \mathrm{xpa}^{-/-}$status as well as heterozygosity for the polymerase gene (poln or poll) and backcrossed into the SKH1/xpa ${ }^{-/-}$background for at least six generations $\left[^{70}\right]$. Double knockout mice will be bred by crossing homozygous $\mathrm{F} 7$

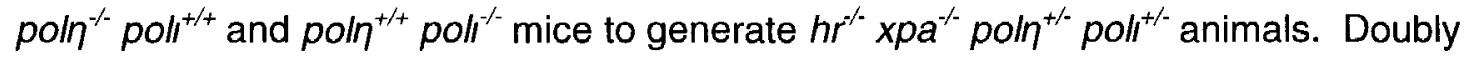
heterozygous littermates will be mated to obtain homozygous knockouts at all four loci. We have F2 poln mice and F2 poll mice in hand and expect to complete back crosses by fall 2008. 


\section{UV Irradiation protocol}

A control group of $40 \mathrm{SKH} 1 /$ hairless $\mathrm{xpa}^{-/-}$mice were segregated according to gender to prevent breeding over the course of the experiment and were housed in groups of five. The UV-B irradiation source is a bank of seven fluorescent FS40 T12 UV-B sources (Westinghouse) that is placed $\sim 40 \mathrm{~cm}$ directly above the cages. (Pictures of the UV bed are included in Section F, Vertebrate Animals.) These lamps have a spectrum of $250-400 \mathrm{~nm}$, peaking at $\sim 310 \mathrm{~nm}$. The lamps were shielded with Kodacel, which removes any short wave UV below $280 \mathrm{~nm}$. The fluence wass determined at 313 $\mathrm{nm}$ using an International Light Radiometer with UVB-1 filter. The dorsal dose to the mice was $200 \mathrm{~J} / \mathrm{m}^{2}$ per week, delivered in three exposures per week. This dose has been determined as the lowest exposure level causing mild erythema (the minimal erythema dose, MED) in our laboratory (unpublished observations). However, if the mice develop erythema, the UV fluence to all groups will be reduced. After 4, 6, 8, or 10 weeks of such exposure, the UV irradiation was discontinued. The mice were examined weekly for tumor development and tumors were confirmed by two observations in which the volume of the tumor had increased. The mice were sacrificed if a tumor reached $10 \%$ of the animal's body mass. All mice were sacrificed 20 weeks after UV treatment initiation. 


\section{RESULTS}

To determine the total UV dose necessary to ensure $100 \%$ of treated mice get tumors, we divided 20 male and 20 female SKH1/hairless xpa ${ }^{-1}$ mice into four groups. Each group had five males and five females and was housed in groups of five segregated by sex. We irradiated the mice with a dorsal dose of $66 \mathrm{Jm}^{-2} \mathrm{UVB}$ three times weekly. Group one was irradiated for four weeks (total dose $\sim 800 \mathrm{Jm}^{-2}$ ), group two for six weeks (total dose $\sim 1,200 \mathrm{Jm}^{-2}$ ), group three for 8 weeks (total dose $\sim 1,600$ $\mathrm{Jm}^{-2}$ ), and group four for 10 weeks (total dose $\sim 2,000 \mathrm{Jm}^{-2}$ ). One hundred percent of group three mice developed tumors with an average latency of $\sim 12$ weeks (Figure 4.1 ). Accordingly, we decided to use the $1,600 \mathrm{Jm}^{-2}$ cumulative dose over six weeks of UV treatment for further experiments. 


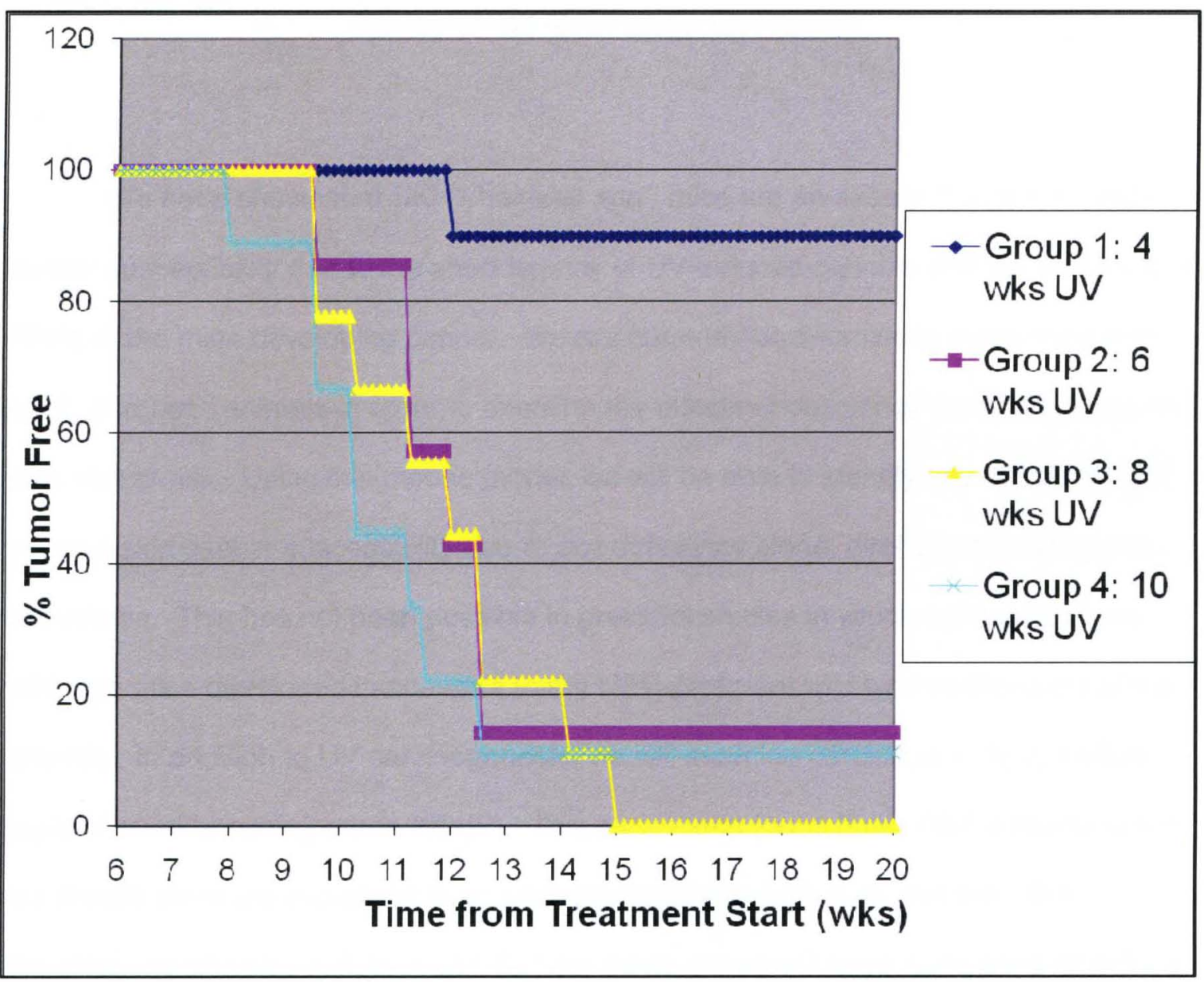

Figure 4.1. Tumor latency of SKH1/hairless $x p a^{-/-}$mice. Four groups of ten mice each were treated with $200 \mathrm{Jm}^{-2}$ for the time periods indicated. Tumor growth was monitored weekly and mice were killed 20 weeks after treatment initiation. 


\section{Conclusions and Future Directions}

We have shown that SKH1/hairless $\mathrm{xpa}^{-/}$mice are an excellent model for skin cancer susceptibility due to the short latency of UV-induced cancers and the likelihood of $100 \%$ of the mice developing cancer. We are currently back-crossing these mice with poln $\eta^{-\alpha}$ and polir animals in order to examine the effects of deficiency for these genes on skin cancer risk. Using this mouse model, we will be able to identify any effects on UVinduced skin cancer susceptibility due to pol/ deficiency alone, directly addressing our hypothesis. This has not been possible in previous studies in which neither poli- nor wild-type mice developed cancer due to the NER-proficient wild type background of the animals. In addition to UV carcinogenesis, we will examine carcinogenesis by topical application of benzo[a]pyrene (B[a]P). This carcinogen forms bulky DNA adducts which our results show are bypassed in an error-prone way by both poln and polı. We therefore hypothesize that mice deficient for these genes will have decreased incidence of $\mathrm{B}[\mathrm{a}] \mathrm{P}$-induced skin cancer.

In addition, we will examine the affects of acute UV and B[a]P exposure on the skin of these mice through histological analysis and immunohistochemical staining. By analyzing appearance of apoptotic and p53-positive cells, in addition to using the TUNEL assay, we will quantify cellular death in response to carcinogen treatment. We hypothesize that poll-deficient mice will display lower levels of cell death after UV, measured partially by the appearance of apoptotic "sunburn cells," in correlation with their proposed increased cancer risk. 


\section{REFERENCES}

[1] The Genetic Basis of Human Cancer, McGraw-Hill, New York, 2007.

[2] V.Amador, S.Ge, P.G.Santamaria, D.Guardavaccaro, M.Pagano. APC/C(Cdc20) controls the ubiquitin-mediated degradation of p21 in prometaphase, Mol Cell., $27,(2007) 462-473$.

[3] D.P.Bartel. MicroRNAs: Genomics, Biogenesis, Mechanism, and Function, Cell, 116, (2004) 281-297.

[4] K.Baynton, A.Bresson-Roy, R.P.Fuchs. Analysis of damage tolerance pathways in Saccharomyces cerevisiae: a requirement for Rev3 DNA polymerase in translesion synthesis, Mol.Cell Biol., 18, (1998) 960-966.

[5] F.A.Beland, F.F.Kadlubar. Formation and persistence of arylamine DNA adducts in vivo, Environ. Health Perspect., 62:19-30., (1985) 19-30.

[6] F.A.Beland, K.L.Dooley, D.A.Casciano. Rapid isolation of carcinogen-bound DNA and RNA by hydroxyapatite chromatography, Journal of Chromatography A, 174, (1979) 177-186.

[7] F.A.Beland, M.Ribovich, P.C.Howard, R.H.Heflich, P.Kurian, G.E.Milo.

Cytotoxicity, cellular transformation and DNA adducts in normal human diploid fibroblasts exposed to 1-nitrosopyrene, a reduced derivative of the environmental contaminant, 1-nitropyrene, Carcinogenesis, 7, (1986) 1279-1283.

[8] R.J.Berg, H.J.van Kranen, H.G.Rebel, A.de Vries, W.A.van Vloten, C.F.van Kreijl, J.C.van der Leun, F.R.de Gruijl. Early p53 alterations in mouse skin carcinogenesis by UVB radiation: Immunohistochemical detection of mutant p53 protein in clusters of preneoplastic epidermal cells, Proceedings of the National Academy of Sciences, 93, (1996) 274-278.

[9] P.R.Bergstresser, C.A.Elmets, A.Takashima, H.Mukhtar. Photocarcinogenesis, Photodermatol.Photoimmunol.Photomed., 11, (1996) 181-184.

[10] X.Bi, D.M.Slater, H.Ohmori, C.Vaziri. DNA polymerase kappa is specifically required for recovery from the benzo[a]pyrene-dihydrodiol epoxide (BPDE)induced S-phase checkpoint, J.Biol.Chem., 280, (2005) 22343-22355.

[11] A.Borgen, H.Darvey, N.Castagnoli, T.T.Crocker, R.E.Rasmussen, I.Y.Wang. Metabolic conversion of benzo(a)pyrene by Syrian hamster liver microsomes and binding of metabolites to deoxyribonucleic acid, J Med.Chem., 16, (1973) 502506. 
[12] T.Boveri. The Origin of Malignant Tumors, Williams and Wilkins, Baltimore, MD, 1929.

[13] D.E.Brash, J.A.Rudolph, J.A.Simon, A.Lin, G.J.McKenna, H.P.Baden, A.J.Halperin, J.Ponten. A Role for Sunlight in Skin Cancer: UV-Induced p53 Mutations in Squamous Cell Carcinoma, Proceedings of the National Academy of Sciences, 88, (1991) 10124-10128.

[14] J.C.Carrington, V.Ambros. Role of MicroRNAs in Plant and Animal Development, Science, 301, (2003) 336-338.

[15] L.Chen, P.D.Devanesan, S.Higginbotham, F.Ariese, R.Jankowiak, G.J.Small, E.G.Rogan, E.L.Cavalieri. Expanded Analysis of Benzo[a]pyrene-DNA Adducts Formed in Vitro and in Mouse Skin: Their Significance in Tumor Initiation, Chem.Res.Toxicol., 9, (1996) 897-903.

[16] L.Chen, P.D.Devanesan, S.Higginbotham, F.Ariese, R.Jankowiak, G.J.Small, E.G.Rogan, E.L.Cavalieri. Expanded analysis of benzo[a]pyrene-DNA adducts formed in vitro and in mouse skin: their significance in tumor initiation, Chem. Res Toxicol., 9, (1996) 897-903.

[17] R.H.Chen, V.M.Maher, J.J.McCormick. Effect of excision repair by diploid human fibroblasts on the kinds and locations of mutations induced by $(+/-)-7$ beta, 8 alpha-dihydroxy-9 alpha, 10 alpha-epoxy-7,8,9,10tetrahydrobenzo[a]pyrene in the coding region of the HPRT gene, Proc.Natl.Acad.Sci.U.S.A, 87, (1990) 8680-8684.

[18] R.H.Chen, V.M.Maher, J.J.McCormick. Lack of a cell cycle-dependent strand bias for mutations induced in the HPRT gene by (+/-)-7 beta, 8 alpha-dihydroxy- 9 alpha, 10 alpha-epoxy-7,8,9,10-tetrahydrobenzo(a)pyrene in excision repairdeficient human cells, Cancer Res., 51, (1991) 2587-2592.

[19] A.de Vries, R.J.Berg, S.Wijnhoven, A.Westerman, P.W.Wester, C.F.van Kreijl, P.J.Capel, F.R.de Gruijl, H.J.van Kranen, H.van Steeg. XPA-deficiency in hairless mice causes a shift in skin tumor types and mutational target genes after exposure to low doses of U.V.B, Oncogene, 16, (1998) 2205-2212.

[20] A.de Vries, M.E.T.Dolle, J.L.M.Broekhof, J.J.A.Muller, E.D.Kroese, C.F.van Kreijl, P.J.A.Capel, J.Vijg, H.van Steeg. Induction of DNA adducts and mutations in spleen, liver and lung of XPA-deficient/lacZ transgenic mice after oral treatment with benzo[a]pyrene: correlation with tumour development, Carcinogenesis, 18, (1997) 2327-2332.

[21] A.de Vries, C.T.van Oostrom, F.M.Hofhuis, P.M.Dortant, R.J.Berg, F.R.de Gruijl, P.W.Wester, C.F.van Kreijl, P.J.Capel, H.van Steeg, . Increased susceptibility to ultraviolet-B and carcinogens of mice lacking the DNA excision repair gene XPA, Nature, 377, (1995) 169-173.

[22] M.F.Denissenko, A.Pao, M.Tang, G.P.Pfeifer. Preferential formation of benzo[a]pyrene adducts at lung cancer mutational hotspots in P53, Science, 274, (1996) $430-432$. 
[23] M.Diaz, N.B.Watson, G.Turkington, L.K.Verkoczy, N.R.Klinman, W.G.McGregor. Decreased frequency and highly aberrant spectrum of ultraviolet-induced mutations in the hprt gene of mouse fibroblasts expressing antisense RNA to DNA polymerase zeta, Mol.Cancer Res., 1, (2003) 836-847.

[24] G.Doumont, A.Martoriati, C.Beekman, S.Bogaerts, P.J.Mee, F.Bureau, E.Colombo, M.Alcalay, E.Bellefroid, F.Marchesi, E.Scanziani, P.G.Pelicci, J.C.Marine. G1 checkpoint failure and increased tumor susceptibility in mice lacking the novel p53 target Ptprv, EMBO J., 24, (2005) 3093-3103.

[25] G.Doumont, A.Martoriati, J.C.Marine. PTPRV is a key mediator of p53-induced cell cycle exit, Cell Cycle., 4, (2005) 1703-1705.

[26] N.Dumaz, H.J.van Kranen, A.de Vries, R.J.Berg, P.W.Wester, C.F.van Kreijl, A.Sarasin, L.Daya-Grosjean, F.R.de Gruijl. The role of UV-B light in skin carcinogenesis through the analysis of $p 53$ mutations in squamous cell carcinomas of hairless mice, Carcinogenesis, 18, (1997) 897-904.

[27] C.A.Dumstorf, A.B.Clark, Q.Lin, G.E.Kissling, T.Yuan, R.Kucherlapati, W.G.McGregor, T.A.Kunkel. Participation of mouse DNA polymerase iota in strand-biased mutagenic bypass of UV photoproducts and suppression of skin cancer, Proc.Natl.Acad.Sci.U.S.A., 103, (2006) 18083-18088.

[28] E.C.Friedberg. DNA damage and repair, Nature, 421, (2003) 436-440.

[29] F.R.Fritzsche, M.Jung, C.Xu, A.Rabien, H.Schicktanz, C.Stephan, M.Dietel, K.Jung, G.Kristiansen. ADAM8 expression in prostate cancer is associated with parameters of unfavorable prognosis, Virchows Arch., 449, (2006) 628-636.

[30] P.E.Gibbs, X.D.Wang, Z.Li, T.P.McManus, W.G.McGregor, C.W.Lawrence, V.M.Maher. The function of the human homolog of Saccharomyces cerevisiae REV1 is required for mutagenesis induced by UV light, Proc.Natl.Acad.Sci.U.S.A, 97, (2000) 4186-4191.

[31] N.Guo, D.V.Faller, C.Vaziri. Carcinogen-induced S-phase arrest is Chk1 mediated and caffeine sensitive, Cell Growth Differ., 13, (2002) 77-86.

[32] D.Hanahan, R.A.Weinberg. The hallmarks of cancer, Cell, 100, (2000) 57-70.

[33] F.Ide, N.lida, Y.Nakatsuru, H.Oda, K.Tanaka, T.Ishikawa. Mice deficient in the nucleotide excision repair gene XPA have elevated sensitivity to benzo[a]pyrene induction of lung tumors, Carcinogenesis, 21, (2000) 1263-1265.

[34] N.Ishikawa, Y.Daigo, W.Yasui, K.Inai, H.Nishimura, E.Tsuchiya, N.Kohno, Y.Nakamura. ADAM8 as a novel serological and histochemical marker for lung cancer, Clin.Cancer Res., 10, (2004) 8363-8370.

[35] R.E.Johnson, C.M.Kondratick, S.Prakash, L.Prakash. hRAD30 mutations in the variant form of xeroderma pigmentosum, Science, 285, (1999) 263-265. 
[36] R.E.Johnson, S.Prakash, L.Prakash. Efficient bypass of a thymine-thymine dimer by yeast DNA polymerase, Poleta, Science, 283, (1999) 1001-1004.

[37] R.E.Johnson, M.T.Washington, L.Haracska, S.Prakash, L.Prakash. Eukaryotic polymerases iota and zeta act sequentially to bypass DNA lesions, Nature, 406, (2000) 1015-1019.

[38] A.Jonason, S.Kunala, G.Price, R.Restifo, H.Spinelli, J.Persing, D.Leffell, R.Tarone, D.Brash. Frequent clones of p53-mutated keratinocytes in normaláhumanáskin, Proceedings of the National Academy of Sciences, 93, (1996) 14025-14029.

[39] T.Kidokoro, C.Tanikawa, Y.Furukawa, T.Katagiri, Y.Nakamura, K.Matsuda. CDC20, a potential cancer therapeutic target, is negatively regulated by $p 53$, Oncogene., ., (2007).

[40] C.W.Lawrence, V.M.Maher. Eukaryotic mutagenesis and translesion replication dependent on DNA polymerase zeta and Rev1 protein, Biochem.Soc.Trans., 29, (2001) 187-191.

[41] K.Lee, J.Nichols, A.Smith. Identification of a developmentally regulated protein tyrosine phosphatase in embryonic stem cells that is a marker of pluripotential epiblast and early mesoderm, Mech.Dev., 59, (1996) 153-164.

[42] Q.Lin, A.B.Clark, S.D.McCulloch, T.Yuan, R.T.Bronson, T.A.Kunkel, R.Kucherlapati. Increased Susceptibility to UV-Induced Skin Carcinogenesis in Polymerase \{eta\}-deficient Mice, Cancer Res, 66, (2006) 87-94.

[43] C.Masutani, M.Araki, A.Yamada, R.Kusumoto, T.Nogimori, T.Maekawa, S.Iwai, F. Hanaoka. Xeroderma pigmentosum variant (XP-V) correcting protein from HeLa cells has a thymine dimer bypass DNA polymerase activity, EMBO J., 18, (1999) 3491-3501.

[44] C.Masutani, R.Kusumoto, A.Yamada, N.Dohmae, M.Yokoi, M.Yuasa, M.Araki, S.Iwai, K.Takio, F. Hanaoka. The XPV (xeroderma pigmentosum variant) gene encodes human DNA polymerase eta, Nature, 399, (1999) 700-704.

[45] J.P.McDonald, E.G.Frank, B.S.Plosky, I.B.Rogozin, C.Masutani, F.Hanaoka, R.Woodgate, P.J.Gearhart. 129-derived strains of mice are deficient in DNA polymerase iota and have normal immunoglobulin hypermutation, J.Exp.Med., 198, (2003) 635-643.

[46] W.G.McGregor, R.H.Chen, L.Lukash, V.M.Maher, J.J.McCormick. Cell cycledependent strand bias for UV-induced mutations in the transcribed strand of excision repair-proficient human fibroblasts but not in repair-deficient cells, Mol.Cell Biol., 11, (1991) 1927-1934.

[47] W.G.McGregor, M.C.Mah, R.W.Chen, V.M.Maher, J.J.McCormick. Lack of correlation between degree of interference with transcription and rate of strand specific repair in the HPRT gene of diploid human fibroblasts, J.Biol.Chem., 270, (1995) 27222-27227. 
[48] W.G.McGregor, D.Wei, R.H.Chen, V.M.Maher, J.J.McCormick. Relationship between adduct formation, rates of excision repair and the cytotoxic and mutagenic effects of structurally-related polycyclic aromatic carcinogens, Mutat.Res., 376, (1997) 143-152.

[49] W.G.McGregor, D.Wei, V.M.Maher, J.J.McCormick. Abnormal, error-prone bypass of photoproducts by xeroderma pigmentosum variant cell extracts results in extreme strand bias for the kinds of mutations induced by UV light, Mol.Cell Biol., 19, (1999) 147-154.

[50] K.McNally, J.A.Neal, T.P.McManus, J.J.McCormick, V.M.Maher. hRev7, putative subunit of hPol[zeta], plays a critical role in survival, induction of mutations, and progression through S-phase, of UV(254 nm)-irradiated human fibroblasts, DNA Repair, 7, (2008) 597-604.

[51] A.Morrison, R.B.Christensen, J.Alley, A.K.Beck, E.G.Bernstine, J.F.Lemontt, C.W.Lawrence. REV3, a Saccharomyces cerevisiae gene whose function is required for induced mutagenesis, is predicted to encode a nonessential DNA polymerase, J.Bacteriol., 171, (1989) 5659-5667.

[52] H.Mukhtar, C.A.Elmets. Photocarcinogenesis: mechanisms, models and human health implications, Photochem.Photobiol., 63, (1996) 356-357.

[53] A.J.Nataraj, J.C.Trent, H.N.Ananthaswamy. p53 gene mutations and photocarcinogenesis, Photochem.Photobiol., 62, (1995) 218-230.

[54] J.R.Nelson, P.E.Gibbs, A.M.Nowicka, D.C.Hinkle, C.W.Lawrence. Evidence for a second function for Saccharomyces cerevisiae Rev1p, Mol.Microbiol., 37, (2000) 549-554.

[55] J.R.Nelson, C.W.Lawrence, D.C.Hinkle. Deoxycytidyl transferase activity of yeast REV1 protein, Nature, 382, (1996) 729-731.

[56] J.R.Nelson, C.W.Lawrence, D.C.Hinkle. Thymine-thymine dimer bypass by yeast DNA polymerase zeta, Science., 272, (1996) 1646-1649.

[57] S.H.Oh, K.H.Kim, S.E.Lee, B.I.Yeh. Identification of mutagenic site of c-H-ras oncogene damaged by $\mathrm{N}$-acetoxyacetylaminofluorene(AAAF), Yonsei Med.J., 32 , (1991) 207-214.

[58] T.Ohkumo, Y.Kondo, M.Yokoi, T.Tsukamoto, A.Yamada, T.Sugimoto, R.Kanao, Y.Higashi, H.Kondoh, M.Tatematsu, C.Masutani, F.Hanaoka. UV-B radiation induces epithelial tumors in mice lacking DNA polymerase eta and mesenchymal tumors in mice deficient for DNA polymerase iota, Mol.Cell Biol., 26, (2006) 7696-7706.

[59] H.Ohmori, E.C.Friedberg, R.P.Fuchs, M.F.Goodman, F.Hanaoka, D.Hinkle, T.A.Kunkel, C.W.Lawrence, Z.Livneh, T.Nohmi, L.Prakash, S.Prakash, T.Todo, G.C.Walker, Z.Wang, R.Woodgate. The Y-family of DNA polymerases, Mol.Cell, 8, (2001) 7-8. 
[60] M.M.Ouellette, L.D.McDaniel, W.E.Wright, J.W.Shay, R.A.Schultz. The establishment of telomerase-immortalized cell lines representing human chromosome instability syndromes, Hum.Mol.Genet., 9, (2000) 403-411.

[61] S.Parrinello, E.Samper, A.Krtolica, J.Goldstein, S.Melov, J.Campisi. Oxygen sensitivity severely limits the replicative lifespan of murine fibroblasts, Nat.Cell Biol., 5, (2003) 741-747.

[62] O.Pelkonen, D.W.Nebert. Metabolism of polycyclic aromatic hydrocarbons: etiologic role in carcinogenesis, Pharmacol Rev, 34, (1982) 189-222.

[63] M.C.POIRIER, G.M.WILLIAMS, S.H.Yuspa. Effect of Culture Conditions, Cell Type, and Species of Origin on the Distribution of Acetylated and Deacetylated Deoxyguanosine C-8 Adducts of N-Acetoxy-2-Acetylaminofluorene, Mol Pharmacol, 18, (1980) 581-587.

[64] M.C.Poirier, M.A.Dubin, S.H.Yuspa. Formation and Removal of Specific Acetylaminofluorene-DNA Adducts in Mouse and Human Cells Measured by Radioimmunoassay, Cancer Res, 39, (1979) 1377-1381.

[65] Z.F.Pursell, I.Isoz, E.B.Lundstrom, E.Johansson, T.A.Kunkel. Yeast DNA polymerase epsilon participates in leading-strand DNA replication, Science., 317, (2007) 127-130.

[66] H.Rebel, L.O.Mosnier, R.J.Berg, A.Westerman-de Vries, H.van Steeg, H.J.van Kranen, F.R.de Gruijl. Early p53-positive foci as indicators of tumor risk in ultraviolet-exposed hairless mice: kinetics of induction, effects of DNA repair deficiency, and p53 heterozygosity, Cancer Res., 61, (2001) 977-983.

[67] O.Rechkoblit, Y.Zhang, D.Guo, Z.Wang, S.Amin, J.Krzeminsky, N.Louneva, N.E.Geacintov. trans-Lesion synthesis past bulky benzo[a]pyrene diol epoxide N2-dG and N6-dA lesions catalyzed by DNA bypass polymerases, J.Biol.Chem., 277, (2002) 30488-30494.

[68] A.N.D.R.ROEMER, L.U.T.Z.SCHWETTMANN, M.O.N.I.JUNG, C.A.R.S.STEPHAN, J.A.N.ROIGAS, G.L.E.N.KRISTIANSEN, S.A.LOENING, R.A.L.F.LICHTINGHAGEN, K.L.A.U.JUNG. THE MEMBRANE PROTEASES ADAMS AND HEPSIN ARE DIFFERENTIALLY EXPRESSED IN RENAL CELL CARCINOMA. ARE THEY POTENTIAL TUMOR MARKERS?, The Journal of Urology, 172, (2004) 2162-2166.

[69] E.G.Rogan, P.D.Devanesan, N.V.RamaKrishna, S.Higginbotham, N.S.Padmavathi, K.Chapman, E.L.Cavalieri, H.Jeong, R.Jankowiak, G.J.Small. Identification and quantitation of benzo[a]pyrene-DNA adducts formed in mouse skin, Chem.Res Toxicol., 6, (1993) 356-363.

[70] A.J.Silva, E.M.Simpson, J.S.Takahashi, H.P.Lipp, S.Nakanishi, J.M.Wehner, K.P.Giese, T.Tully, T.Abel, P.F.Chapman, K.Fox, S.Grant, S.Itohara, R.Lathe, M.Mayford, J.O.McNamara, R.J.Morris, M.Picciotto, J.Roder, H.S.Shin, P.A.Slesinger, D.R.Storm, M.P.Stryker, S.Tonegawa, Y.Wang, D.P.Wolfer. 
Mutant Mice and Neuroscience: Recommendations Concerning Genetic Background, Neuron, 19, (1997) 755-759.

[71] P.Sims, P.L.Grover. Epoxides in polycyclic aromatic hydrocarbon metabolism and carcinogenesis, Adv.Cancer Res., 20:165-274., (1974) 165-274.

[72] D.C.Thomas, X.Veaute, R.P.Fuchs, T.A.Kunkel. Frequency and fidelity of translesion synthesis of site-specific $\mathrm{N}$-2-acetylaminofluorene adducts during DNA replication in a human cell extract, J.Biol.Chem., 270, (1995) 21226-21233.

[73] B.S.Tung, W.G.McGregor, Y.C.Wang, V.M.Maher, J.J.McCormick. Comparison of the rate of excision of major UV photoproducts in the strands of the human HPRT gene of normal and xeroderma pigmentosum variant cells, Mutat.Res., 362, (1996) 65-74.

[74] H.J.van Kranen, F.R.de Gruijl, A.de Vries, Y.Sontag, P.W.Wester, H.C.Senden, E.Rozemuller, C.F.van Kreijl. Frequent p53 alterations but low incidence of ras mutations in UV-B-induced skin tumors of hairless mice, Carcinogenesis, 16, (1995) 1141-1147.

[75] H.J.van Kranen, A.de Laat, d.van, V, P.W.Wester, A.de Vries, R.J.Berg, C.F.van Kreijl, F.R.de Gruijl. Low incidence of p53 mutations in UVA (365-nm)-induced skin tumors in hairless mice, Cancer Res., 57, (1997) 1238-1240.

[76] Y.C.Wang, V.M.Maher, D.L.Mitchell, J.J.McCormick. Evidence from mutation spectra that the UV hypermutability of xeroderma pigmentosum variant cells reflects abnormal, error-prone replication on a template containing photoproducts, Mol.Cell Biol., 13, (1993) 4276-4283.

[77] M.Watanabe, V.M.Maher, J.J.McCormick. Excision repair of UV- or benzo[a]pyrene diol epoxide-induced lesions in xeroderma pigmentosum variant cells is 'error free', Mutat.Res., 146, (1985) 285-294.

[78] M.Watanabe, V.M.Maher, J.J.McCormick. Excision repair of UV- or benzo[a]pyrene diol epoxide-induced lesions in xeroderma pigmentosum variant cells is 'error free', Mutat.Res., 146, (1985) 285-294.

[79] R.S.Weiss, P.Leder, C.Vaziri. Critical Role for Mouse Hus1 in an S-Phase DNA Damage Cell Cycle Checkpoint, Mol.Cell.Biol., 23, (2003) 791-803.

[80] J.G.Westra, E.Kriek, H.Hittenhausen. Identification of the persistently bound form of the carcinogen $\mathrm{N}$-acetyl-2-aminofluorene to rat liver DNA in vivo, Chem.Biol.Interact., 15, (1976) 149-164.

[81] D.Wildeboer, S.Naus, Q.X.my Sang, J.W.Bartsch, A.Pagenstecher. Metalloproteinase disintegrins ADAM 8 and ADAM 19 are highly regulated in human primary brain tumors and their expression levels and activities are associated with invasiveness, J.Neuropathol.Exp.Neurol., 65, (2006) 516-527.

[82] A.Wood, P.Garg, P.M.J.Burgers. A Ubiquitin-binding Motif in the Translesion DNA Polymerase Rev1 Mediates Its Essential Functional Interaction with 
Ubiquitinated Proliferating Cell Nuclear Antigen in Response to DNA Damage, Journal of Biological Chemistry, 282, (2007) 20256-20263.

[83] J.L.Yang, V.M.Maher, J.J.McCormick. Amplification and direct nucleotide sequencing of CDNA from the lysate of low numbers of diploid human cells, Gene., 83, (1989) 347-354.

[84] M.Yasui, H.Dong, R.R.Bonala, N.Suzuki, H.Ohmori, F.Hanaoka, F.Johnson, A.P.Grollman, S.Shibutani. Mutagenic Properties of 3-(Deoxyguanosin-N2-yl)-2acetylaminofluorene, a Persistent Acetylaminofluorene-Derived DNA Adduct in Mammalian Cells, Biochemistry, 43, (2004) 15005-15013.

[85] F.Yuan, Y.Zhang, D.K.Rajpal, X.Wu, D.Guo, M.Wang, J.S.Taylor, Z.Wang. Specificity of DNA lesion bypass by the yeast DNA polymerase eta, J.Biol.Chem., 275, (2000) 8233-8239.

[86] W.Zhang, J.E.Dahlberg, W.Tam. MicroRNAs in tumorigenesis: a primer, Am.J.Pathol., 171, (2007) 728-738.

[87] Y.Zhang, X.Wu, D.Guo, O.Rechkoblit, N.E.Geacintov, Z.Wang. Two-step errorprone bypass of the (+)- and (-)-trans-anti-BPDE-N2-dG adducts by human DNA polymerases eta and kappa, Mutat.Res., 510, (2002) 23-35.

[88] Y.Zhang, F.Yuan, X.Wu, O.Rechkoblit, J.S.Taylor, N.E.Geacintov, Z.Wang. Error-prone lesion bypass by human DNA polymerase eta, Nucleic Acids Res., $28,(2000)$ 4717-4724.

[89] Y.Zhang, F.Yuan, X.Wu, J.S.Taylor, Z.Wang. Response of human DNA polymerase iota to DNA lesions, Nucleic Acids Res., 29, (2001) 928-935.

[90] Y.Zhang, F.Yuan, X.Wu, M.Wang, O.Rechkoblit, J.S.Taylor, N.E.Geacintov, Z.Wang. Error-free and error-prone lesion bypass by human DNA polymerase kappa in vitro, Nucleic Acids Res., 28, (2000) 4138-4146.

[91] Y.Zhang, X.Wu, D.Guo, O.Rechkoblit, Z.Wang. Activities of human DNA polymerase [kappa] in response to the major benzo[a]pyrene DNA adduct: errorfree lesion bypass and extension synthesis from opposite the lesion, DNA Repair, 1, (2002) 559-569.

[92] B.Zhao, J.Wang, N.E.Geacintov, Z.Wang. Poleta, Polzeta and Rev1 together are required for $G$ to $T$ transversion mutations induced by the (+)- and (-)-transanti-BPDE-N2-dG DNA adducts in yeast cells, Nucleic Acids Res., 34, (2006) 417-425.

[93] B.B.Zhou, S.J.Elledge. The DNA damage response: putting checkpoints in perspective, Nature., 408, (2000) 433-439.

[94] A.Ziegler, A.S.Jonason, D.J.Leffellt, J.A.Simon, H.W.Sharma, J.Kimmelman, L.Remington, T.Jacks, D.E.Brash. Sunburn and p53 in the onset of skin cancer, Nature, 372, (1994) 773-776. 
[95] L.Zou, S.J.Elledge. Sensing DNA damage through ATRIP recognition of RPAssDNA complexes, Science., 300, (2003) 1542-1548.

[96] L.Zou, D.Liu, S.J.Elledge. Replication protein A-mediated recruitment and activation of Rad17 complexes, Proc.Natl.Acad.Sci.U.S.A., 100, (2003) 1382713832. 


\section{APPENDIX}

\section{List of Abbreviations}

7-AAD 7-aminoactinomycin D

AAAF N-acetoxy-2-acetylaminofluorene

ATM Ataxia telangiectasia mutated

ATR Ataxia telangiectasia related

$\mathrm{B}[\mathrm{a}] \mathrm{P} \quad$ Benzo[a]pyrene

BPDE 7R,8S-dihydroxy-9S,10R-epoxy-7,8,9,10-tetrahydrobenzo[a]pyrene

BrdU Bromodeoxyuridine

CPD Cyclobutane pyrimidine dimer

DMEM Dulbecco's modified Eagle's medium

DNA Deoxyribonucleic acid

FACS Fluorescence activated cell sorting

FBS Fetal bovine serum

HPRT Hypoxanthine phosphoribosyltransferase

IVT In vitro transcription

miRNA Micro-ribonucleic acid

mRNA Messenger ribonucleic acid

NER Nucleotide excision repair

NMSC Non-melanoma skin cancer

NOP 1-nitrosopyrene

nt nucleotide

PBS Phosphate-buffered saline

PCNA Proliferating cell nuclear antigen

pol Polymerase 


$\begin{array}{ll}\text { RAD } & \text { Radiation sensitive } \\ \text { REV } & \text { Reversionless } \\ \text { RPA } & \text { Replication protein A } \\ \text { TG } & \text { 6-Thioguanine } \\ \text { TLS } & \text { Translesion synthesis } \\ \text { Trp53 } & \text { Transformation related protein } 53 \\ \text { TUNEL } & \text { Terminal deoxynucleotidyl transferase dUTP nick end labeling } \\ \text { UV } & \text { Ultraviolet } \\ \text { XP } & \text { Xeroderma Pigmentosum }\end{array}$




\section{CURRICULUM VITA}

\section{BIOGRAPHICAL}

$\begin{array}{llll}\text { Name: } & \begin{array}{l}\text { Lindsey Jay Stallons } \\ \text { Home Address: }\end{array} & \begin{array}{l}\text { Birth Date: } \\ \text { 3606 Locust Ave } \\ \text { Louisville, KY } 40299\end{array} & \text { Birth Place: } \\ \text { Home Phone: } & \begin{array}{l}502-558-8507 \\ \text { Business Address: }\end{array} & \\ & \begin{array}{l}\text { Dept of Pharmacology } \\ \text { 570 South Preston Street } \\ \text { Room 226 } \\ \text { Louisville, KY 40202 }\end{array} & \text { Citizenship: USA } \\ & \end{array}$

E-Mail: ljstal01@louisville.edu

Business Phone: $\quad 502.852 .2115$

Business Fax: 502.852.2492

\section{EDUCATION AND TRAINING}

\section{UNDERGRADUATE}

\section{Dates attended \\ Major subject}

$2003-2006$

Chemistry

$2002-2003$

Chemistry

\section{Name and location of institution}

University of Louisville

Louisville, KY

Centre College

Danville, $\mathrm{KY}$
Degree received and date

Bachelor of Science

May 2006

Transfer

May 2003 
GRADUATE

Dates attended

Major subject

$2006-2008$

Pharmacology \&

Toxicology

2008 - Present

Pharmacology \& Toxicology
Name and location of institution

University of Louisville

Louisville, KY

University of Louisville

Louisville, KY
Degree received and date

Masters of Science

August 2008

Doctor of Philosophy

Anticipated August 2010

ACADEMIC:

\section{PROFESSIONAL EXPERIENCE}

$\begin{array}{lll}\begin{array}{c}\text { Years } \\ \text { inclusive }\end{array} & \begin{array}{l}\text { Name and location of institution, } \\ \text { department and mentor/supervisor }\end{array} & \text { Title } \\ 2004 \text { - 2005 } & \begin{array}{l}\text { University of Louisville } \\ \text { Louisville, KY } \\ \text { Dept of Chemistry, Teresa Fan, Ph.D. }\end{array} & \begin{array}{c}\text { Undergraduate } \\ \text { Research } \\ \text { Assistant }\end{array} \\ 2005 \text { - 2006 } & \begin{array}{l}\text { University of Louisville } \\ \text { Louisville, KY }\end{array} & \text { Tutor } \\ & \begin{array}{l}\text { Resources for Academic Achievement, Karen Seng } \\ 2005\end{array} & \\ & \begin{array}{l}\text { University of Louisville } \\ \text { Louisville, KY } \\ \text { Dept of Pharmacology, W. Glenn McGregor, M.D. }\end{array} & \begin{array}{c}\text { Undergraduate } \\ \text { Research } \\ \text { Assistant }\end{array} \\ & & \end{array}$

MEMBERSHIPS in PROFESSIONAL and SCIENTIFIC SOCIETIES

\section{Organization}

Society of Undergraduate Chemistry Students, University of Louisville Vice President

Environmental Mutagen Society

Ohio Valley Society of Toxicology

American Association for Cancer Research
Year

$2004-2006$

$2005-2006$

2007 - Present

2007 - Present

2008 - Present 


\title{
HONORS
}

Title of award, sponsor

Year

Dean's List, Centre College

$2002-2003$

Dean's List, University of Louisville

$2003-2006$

Cancer Education Program Fellowship, University of Louisville

2005

First Place Poster, Research!Louisville

Travel Award, Environmental Mutagen Society

Travel Award, University of Louisville School of Medicine

2007

Travel Award, University of Louisville Graduate Student Council

2007

\section{PROFESSIONAL ACTIVITIES}

\section{SERVICE:}

\section{University of Louisville}

Chair Search Committee, Dept of Biochemisty \& Molecular Biology 2007 - Present MENTORING:

\section{University of Louisville}

Undergraduates

\author{
Brian Sils \\ Robert Skaggs \\ Anthony Smith \\ Christopher Belcher \\ Caleb Greenwell
}




\section{PRESENTATIONS:}

\section{Local/Regional}

2005 Poster Presenter, Research Louisville, UofL Chronic Inflammation Does Not Alter Patterns of Gene Expression in Carcinogen-Initiated Lung Cancer

2006

Poster Presenter, Posters-at-the-Capitol, Frankfort, KY Chronic Inflammation Does Not Alter Patterns of Gene Expression in Carcinogen-Initiated Lung Cancer

Seminar, Dept. of Pharmacology, UofL

Human DNA polymerase $\eta$ is error-free when bypassing UV photoproducts but error-prone when bypassing benzo[a]pyrene adducts in vivo.

2007 Seminar, Student Meeting of the Ohio Valley Society of Toxicology, Louisville, $\mathrm{KY}$

Human DNA polymerase $\eta$ is error-free when bypassing UV photoproducts but error-prone when bypassing benzo[a]pyrene adducts in vivo.

$2007 \quad 1^{\text {st }}$ Place Poster, Basic Science Masters Student, Research!Louisville, UofL

$D N A$ polymerase eta is the preferred translesion DNA polymerase and may be error-free or error-prone: evidence from mutation spectra.

2007 Poster Presenter, Ohio Valley Society of Toxicology Annual Meeting, Indianapolis, IN

Poln and Poll are Required for Mutagenic Bypass of BPDE Lesions in Primary Murine Fibroblasts

Poster Presenter, JG Brown Cancer Center Annual Retreat, Louisville, $\mathrm{KY}$

Poln and Poll are Required for Mutagenic Bypass of BPDE Lesions in Primary Murine Fibroblasts 


\section{National / International}

2007

Platform Presentation, Environmental Mutagen Soc. National Meeting, Atlanta, GA

Evidence from Mutation Spectra that DNA Polymerase eta is the Preferred Translesion DNA Polymerase and May Be ErrorFree or Error-Prone

2008 Platform Presentation, Environmental Mutagen Soc. National Meeting, Rio Grande, Puerto Rico

Cell Death and Cell Cycle Pathways as Potential Targets for Tumor Suppression by Pol lota: A Systems Biology Approach

\section{RESEARCH}

\section{FUNDING}

\section{Current Grant}

Support:

\begin{tabular}{lllll} 
Grant Source & Grant Title & $\begin{array}{l}\text { Role in Project } \\
\text { and \% of Effort }\end{array}$ & $\begin{array}{l}\text { Years } \\
\text { Inclusive }\end{array}$ \\
\cline { 1 - 3 } NIEHS & U of L & T32 100\% & $12 / 2007-$ \\
ES011564 & $\begin{array}{l}\text { Environmental } \\
\text { Health Sciences } \\
\text { Training Program }\end{array}$ & Fellow & & $11 / 2008$ \\
& T32 & & \\
& & & &
\end{tabular}

\section{LIST of CURRENT RESEARCH INTERESTS:}

a. Understand the cellular roles played by $Y$ family polymerases in response to structurally varied DNA adducts

b. Utilize emerging nanotechnologies to develop targeted markers for imaging and treatment of skin and lung cancer.

c. Investigate the therapeutic effects of arsenic in mouse models of UVinduced skin cancer.

\section{COMMUNITY INVOLVEMENT}

Co-Captain, OneCorps Activist Group, Louisville, KY

2006 - Present 